
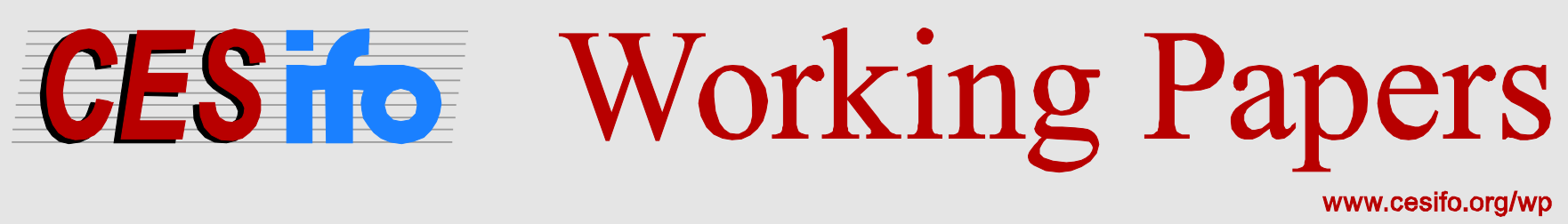

\title{
Patent Boxes Design, Patents Location and Local R\&D
}

\author{
Annette Alstadsæter \\ Salvador Barrios \\ Gaetan Nicodeme \\ Agnieszka Maria Skonieczna \\ Antonio Vezzani
}

CESIFO WORKING PAPER NO. 5416

CATEGORY 1: PUBLIC FINANCE

JUNE 2015

Presented at CESifo Area Conference on Public Sector Economics, April 2015

An electronic version of the paper may be downloaded

- from the SSRN website:

- from the RePEc website:

- from the CESifo website:

WwW.SSRN.com

www.RePEc.org

www.CESifo-group.org/wp 


\title{
Patent Boxes Design, Patents Location and Local R\&D
}

\begin{abstract}
Patent boxes have been heavily debated for their role in corporate tax competition. This paper uses firm-level data for the period 2000-2011 for the top 2,000 corporate research and development (R\&D) investors worldwide to consider the determinants of patent registration across a large sample of countries. Importantly, we disentangle the effects of corporate income taxation from the tax advantage of patent boxes. We also exploit a new and original dataset on patent box features such as the conditionality on performing research in the country, and their scope. We find that patent boxes have a considerable effect on attracting patents, mostly because of their favourable tax treatment, especially for high-quality patents. Patent boxes with a large scope in terms of tax base definition also have stronger effects on the location of patents. The size of the tax advantage offered through patent box regimes is found to deter local innovative activities, whereas R\&D development conditions tend to attenuate this adverse effect. Our simulations show that, on average, countries imposing such development conditions tend to grant a tax advantage that is slightly greater than optimal from a local $R \& D$ impact perspective.
\end{abstract}

JEL-Code: F210, F230, H250, H730, O310, O340.

Keywords: corporate taxation, patent boxes, location, patents, R\&D, nexus approach.

\author{
Annette Alstadsceter \\ University of Oslo / Norway \\ annette.alstadsater@medisin.uio.no \\ Gaetan Nicodeme \\ European Commission \\ gaetan.nicodeme@ec.europa.eu
}

\author{
Salvador Barrios* \\ European Commission \\ salvador.barrios@ec.europa.eu \\ Agnieszka Maria Skonieczna \\ European Commission \\ Agnieszka- \\ Maria.Skonieczna@ec.europa.eu
}

\author{
Antonio Vezzani \\ European Commission \\ Antonio.Vezzani@ec.europa.eu
}

*corresponding author

June 2015

We are thankful to Maarten Buis, David Hannigan, Shafik Hebous, Henrik Paulander, Eric Strobl, Sara Riscado and the participants in the 2015 PSE CESifo conference for valuable comments and suggestions. The findings, interpretations and conclusions expressed in this paper are entirely those of the authors and should not be attributed to the European Commission. Possible errors and omissions are those of the authors and theirs only. 


\section{Introduction}

A growing number of developed economies have recently implemented patent box regimes. Those grant preferential tax treatment to corporate revenues from intellectual property (IP). The use of such schemes has raised suspicion about yet another tax competition device. In July 2013, the German finance minister, Wolfgang Schäuble, publicly criticised patent box regimes as 'going against the European spirit', suggesting that they should simply be banned. ${ }^{1}$ Such concerns appear justified by anecdotal evidence. For instance, Pfizer's widely discussed and failed attempt to takeover Astra Zeneca appeared to be essentially tax motivated. ${ }^{2}$ The company resulting from this merger would have been incorporated in the UK taking advantage of a reduced corporate tax rate of $10 \%$ (instead of a standard rate of $21 \%$ ) over future profits generated from patents. Similarly, the UK company GlaxoSmithKline has recently centralised all its vaccine-related IP in Belgium mainly for fiscal reasons while carrying its physical capital investment at home. ${ }^{3}$ In another notable case, the hotel reservation company Booking.com was expected to reduce its tax rate by around 4 percentage points thanks to the Dutch patent box regime. ${ }^{4}$ These examples seem to suggest that the decisions on patent registration by firms may have little to do with developing research and innovation but a lot to do with tax planning, echoing Minister Schäuble's worries that patent boxes are simply there 'to attract companies'. Such concerns were also voiced in the context of the Organisation for Economic Cooperation and Development (OECD) Base Erosion and Profit Shifting (BEPS) discussion and in the EU code of conduct on business taxation. ${ }^{5}$ The need to align taxation with 'substantial' research activity being developed by companies is now indeed seen as a key factor to ensure that such preferential regimes reach their goal of fostering innovation and economic growth. ${ }^{6}$

In this paper, we provide novel empirical evidence on the determinants of the geographical distribution of patent applications made by the 2,000 top corporate R\&D investors. We focus on both tax and non-tax features of patent box regimes that might affect

\footnotetext{
${ }^{1}$ Breidthardt, A., 'Germany calls on EU to ban "patent box" tax breaks', Reuters, 9 July 2013, http://uk.reuters.com/article/2013/07/09/uk-europe-taxes-idUKBRE9680KY20130709

${ }^{2}$ Financial Times, 29 April, 2014

${ }^{3}$ See Financial Times, 12 March 2014 and "GSK renforce le rôle de la Belgique comme QG mondial", L'Echo, 7 April 2015.

${ }^{4}$ Breidthardt, A., 'Germany calls on EU to ban "patent box" tax breaks', Reuters, 9 July 2013, http://uk.reuters.com/article/2013/07/09/uk-europe-taxes-idUKBRE9680KY20130709

5 OCDE (2014), pages 27-53.

6 Van der Made $(2014,2015)$.
} 
patent registration and local R\&D activity. Our sample covers 33 countries (the EU28, the USA, Canada, Switzerland, the Republic of Korea and China) and three sectors of activity (the pharmaceutical industry, the car industry and the Information and Communications Technology, ICT), which have been particularly active in global patenting in the past decades. We disentangle the general effects of the corporate income tax (CIT) rate from tax and nontax characteristics of patent boxes such as their scope and eligibility conditions, and investigate whether or not these characteristics influence local research activity. Importantly, our firm-level data includes 12 countries with patent boxes, of which 10 have introduced a patent box within the period 2000-2011. To the best of our knowledge, this is the first attempt to analyse the various specific designs of patent boxes and to test their impacts on patent location and local inventorship. Our results suggest that patent boxes have a strong effect on attracting high-value patents, mainly owing to the favourable tax treatment they offer. Patents are also found to be more sensitive to the tax advantages offered by patent boxes when these have a large scope in terms of IP covered, and when they grant their benefit to pre-existing patents, acquired patents and/or embedded royalties. Interestingly, our results indicate that the tax advantages of patent boxes tend to deter local innovative activities, given the lack of incentives for companies to develop local research. Nevertheless, our results suggest that the imposition of local R\&D development conditions in the patent box regime has the potential to attenuate this adverse fiscal effect. Our simulations show that on average countries imposing such development conditions actually tend to grant a tax advantage that is larger than optimal from a local R\&D impact perspective, although only slightly so.

There is to date little empirical evidence on the impacts of patent boxes on R\&D and patent location. A negative relationship between the level of the corporate income tax rate and the amounts of both a firm's intangible assets and its patents has been documented by Dischinger and Riedel (2011), Ernst and Spengel (2011), Karkinsky and Riedel (2012), Böhm et al. (2014), Ernst et al. (2014), and Griffith et al. (2014). For example, Karkinsky and Riedel (2012) estimate that a percentage point increase in the corporate tax rate reduces patent applications filed at the location by around 3.5\%. Böhm et al. (2014) and Griffith et al (2014) show in addition that the quality of an intangible asset and the anti-avoidance framework (controlled foreign company, CFC, rules) play a role in the location decisions. Böhm et al. (2014) and Ernst et al. (2014) suggest that low income tax rates attract particularly patents with high earning potential. However, these papers use older data that do not cover the introduction of the many recent patent boxes, often mainly analysing the effect 
of the (effective) CIT rate on the patent location choices. For instance, Griffith et al. (2014) estimate ex ante, with data running until 2005, the impact of preferential tax regimes for patent income and conclude that they are likely to result in substantial revenue losses for all countries.

The rising concerns surrounding patent boxes are part of a long-standing discussion on tax competition. This literature usually advocates for an increased global coordination of corporate tax policies. Countries around the world have always been eager to be attractive to foreign portfolio and physical investment, thus triggering a race to the bottom in corporate taxation, realising the theoretical predictions of Zodrow and Mieszkowski (1986) and Wilson (1986). ${ }^{7}$ In the OECD, the average CIT rates fell from $48.5 \%$ in 1985 to $28.7 \%$ in 2007, while in the EU (EU-15) the fall was from $48.7 \%$ in 1985 to $28.8 \%$ in 2007 . Recently, however, this race to the bottom seems to have levelled off. The EU-15 average moved from $27.5 \%$ in 2008 to $26.3 \%$ in 2015 and the OECD average changed from $27.6 \%$ to $26.4 \%$ over the same period. $^{8}$ At the same time, many EU Member States narrowed their tax base in corporate taxation with a view to stimulating investment. ${ }^{9}$ Tax competition thus seems to have changed its nature, moving from a focus on statutory rates to one on tax bases. Patent boxes are an important driver of these recent developments, with EU countries being especially active. Figure 1 shows that the number of patent boxes in the EU has grown from 2 in 1995 to 11 in 2015 with a clear acceleration in recent years. The tax reduction that patent boxes offer varies across countries but the average tax advantage over the period has been about a $75 \%$ reduction in the CIT rate (17.9 percentage points).

Theoretically, there are a number of reasons for suggesting that patent boxes do not necessarily serve the goal of boosting local R\&D activity. First, unlike expense-based tax incentives for $R \& D$, such schemes do not reward firms for the social benefits that they cannot appropriate. Instead, they award additional tax benefits to a successful innovation that already enjoys IP protection. Un-patentable research efforts with potentially higher social spillovers are less attractive and thus become indirectly discriminated against. Second, patent boxes also rank very low in terms of good tax incentive practices such as their scope (determining the

\footnotetext{
${ }^{7}$ See Devereux et al. (2008) for an empirical analysis. Data on corporate tax rates can be found in, inter alia, European Commission (2014b) and OECD (2015a).

8 The EU-28 average moved from $22.7 \%$ in 2008 to $22.1 \%$ in 2015 . The OECD data are for those that were members in 1985.

${ }^{9}$ See Garnier et al (2014) for a recent review on policy measures at EU level.
} 
size of the tax base), their targeting and their organisational practices (CPB, 2015). ${ }^{10}$ Finally, the patent box schemes came under the scrutiny of the EU and OECD because of the apparent lack of linkage between the tax advantage offered and the presence of research or innovation activity. Discussions at both the OECD and the EU have led to an agreement on the requirement to establish a nexus between the income derived from IP and the expenditure incurred to develop this asset, for the income to qualify for the patent box preferential regime (OECD, 2014). ${ }^{11}$ The existence of development conditions in some patent boxes may shed light on the potential effect of the nexus condition developed by the OECD and the EU, notably with regard to its effect on patent location, tax revenues and local R\&D. Our finding that the tax-sensitivity of patent location is reduced when such specific conditionality is imposed would suggest that the nexus approach could (at least partly) inhibit the still dominant tax competition dimension of patent boxes.

The remainder of the paper is organised as follows. Section 2 describes patent box regimes and their characteristics and details the nexus approach chosen by developed economies. Section 3 explains our empirical strategy and section 4 describes our dataset. Next, section 5 discusses our results before section 6 concludes.

\section{Patents, patent box design and local R\&D}

\subsection{Who patents and why?}

Before moving into the analysis on the location of patents, it is useful to understand why companies patent their inventions in the first place and why it is strategically important to locate patent for fiscal reason, in particular for large multinationals. A patent is a 'legal title that gives inventors the right, for a limited period (usually 20 years), to prevent others from making, using or selling their invention without their permission in the countries for which the patent has been granted'. ${ }^{12}$ The patent system is territorial, and a patent is valid for the geographical area for which it is granted. This has the effect of dividing world markets

\footnotetext{
${ }^{10} \mathrm{CPB}$ (2015) reviews the economic literature on the determinants of R\&D activity to benchmark the tax schemes. Patent boxes are found to have several non-recommended practices such as being related to output or having weak targeting.

${ }^{11}$ In the EU, an agreement on a modified nexus approach requires that Member States with patent boxes that do not meet this condition close them to new entrants by 30 June 2016 and abolish them by the 30 June 2021 (van der Made, 2015).

${ }^{12}$ Definition according to the European Patent Office: http://www.epo.org/service-support/glossary.html.
} 
into protected trade areas (Greenhalgh and Rogers, 2010). ${ }^{13}$ Holders of a patent issued by a patent office have a given period of time (12 months) to file a patent application abroad and still claim priority for the existing application.

Large R\&D-intensive firms tend to patent more, whereas process-oriented innovators patent less than product-oriented innovators (Peeters and van Pottelsberghe, 2006). Many sectors are not patent-active, and patenting firms represent a small part of the population of firms, e.g. only between $1.6 \%$ in Ireland and $8.8 \%$ in Germany (OECD, 2013). Hall et al. (2013) find that even among firms that conduct R\&D in the UK, only $4 \%$ patent. The share of patenting firms is much lower than one might expect given that around $20 \%$ of firms that invest in R\&D report product innovations. Findings are similar for the USA as only $5.5 \%$ of US manufacturing firms own a patent (Balasubramanian and Sivadasan, 2011). The use of patents by industry reflects this heterogeneity. Computers, electronics, machinery, chemicals and pharmaceuticals are the sectors with the highest patenting activities (OECD, 2013). The most important objective behind patenting is to prevent third parties from exploiting the protected invention. However, strategic patenting seems increasingly important and may also provide signals to rivals, potential negotiation leverage and boost to reputation, but also incentives for R\&D employees and the measurement of performance (Blind et al., 2006). Empirical evidence suggests that, for many sectors patents, are an ineffective way to appropriate returns and secrecy, and lead times are used extensively (Arundel, 2001; Hanel 2008; Hall et al., 2013). This does not necessarily mean that different means of appropriation are substitutes, as for non-patentable inventions such as software in Europe. Firms can combine formal (patents, copyrights, trademarks) and informal (secrecy, lead times) means of appropriation and treat them as complements to protect different elements of their innovation (Hall et al., 2013, 2014). This is important for our work, as the evidence presented in this paper suggests that many patent boxes apply to IP, which is much broader than patents. Furthermore, even for large, $R \& D$-intensive firms coming from sectors where patents are used intensively, differences in strategy remain (Dernis et al., 2015). We are interested in these differences, as we expect that responses to patent boxes will vary across sector. Indeed, the motives for patenting can differ across sectors, for example depending on whether an industry mainly produces 'discrete' or 'complex' products (Cohen et al, 2000).

\footnotetext{
13 This means, for instance, that a US company holding a US patent (granted by the United States Patent and Trademark Office, USTPO) would need to file for patent/register with the European Patent Office (EPO) or a national patent office to obtain a patent that also covers European countries
} 


\subsection{Patent Boxes: a European story}

The European patent system, which is more specifically considered in this paper, is rather complex. The patent applicant have a choice between following the national procedure in each state for which (s)he seeks protection and taking the European route with the European Patent Office (EPO), which in a single procedure confers protection in all the designated contracting states. However, the EPO applicant will still need to validate the European patent in the designated states within a short time limit after the EPO grants the patent (usually 3 months). This could entail a substantial cost due to a number of requirements, such as payment of the fees and translations. ${ }^{14}$

Patent boxes first appeared in France and Ireland as early as the 1970s. Interestingly, Ireland is, to date, the only country that has abolished its patent box for budgetary reasons (2010), but its re-introduction is under consideration at the time of writing of this paper. ${ }^{15}$ Patent boxes are very heterogeneous in their design. These differences are shown in more detail in Table 2. We focus on five design characteristics that are expected to make the tax advantage more or less pronounced: (a) which IP rights qualify for the patent box (the scope); (b) the treatment of existing patents; (c) the treatment of acquired patents; (d) the treatment of embedded royalties; and (e) the existence of development conditions.

First, the name 'patent boxes' can be deceptive, as many patent boxes have a much larger scope than just patentable rights, as summarised in Table 1. All patent boxes cover patents and often rights equivalent to patents such as supplementary protection certificates. Besides patents, patent boxes can also cover designs and, to a lesser extent, trademarks. In addition, they often consider copyrights, sometimes with a restriction to software, probably to compensate for the fact that software is not patentable in Europe unlike in the USA. Firms often combine different forms of IP, even for the same invention (Hall, 2014). This implies that the advantage conferred by patent boxes with a wide IP scope could be more generous than intended by policymakers and would over-subsidise the same invention.

\footnotetext{
${ }^{14}$ Patenting in the EU is expected to become less complex and costly thanks to the introduction of the European patent with unitary effect, the so-called "unitary patent" (European Commission, 2011). Such patent will be yet another option for users besides already-existing national and "classical" European patents. It will enable a unitary effect in $25 \mathrm{EU}$ states without the need for subsequent validation. However, the system is not yet in force. The unitary patent may be requested from the date of the entry into force of the Agreement on a Unified Patent Court. The Agreement was signed by 25 EU Member States on 19 February 2013. It will need to be ratified by at least 13 states, including France, Germany and the United Kingdom to enter into force.

${ }^{15}$ Department of Finance, 'Department of Finance Launches Consultation Process on Knowledge Development Box', 14 January 2015, http://www.finance.gov.ie/news-centre/press-releases/department-finance-launchesconsultation-process-knowledge-development.
} 
Second, the effects of a patent box on tax revenues depend on its provisions. Existing (i.e. prior) patents may in some cases also benefit from the lower tax rates of patent boxes, as in the systems put in place in Cyprus, France, Hungary, Malta, Spain, the UK, Ireland (up to 2010), Liechtenstein and the Nidwalden canton in Switzerland. This represents a windfall gain to firms with existing patents, as after-tax income from their existing patents in that jurisdiction increases with no further action required.

Third, the treatment of acquired patents differs across patent boxes. A majority of patent boxes allow patents acquired from related or third parties, whereas only a small number of countries allow the use of acquired patents on condition that the acquirer further develops these patents.

Fourth, patent boxes also vary in the treatment of embedded royalties. The three 'narrowest' patent boxes in terms of coverage (in the UK, Belgium and The Netherlands) include only income from patents under their IP tax rules (see Table 1). However, at the same time, these patent boxes also include the embedded royalties in the calculation of eligible income. ${ }^{16}$ This means that the income from the sale of products that include patented items and the notional royalty from using patented industrial processes, fall under the patent box, implicitly increasing the coverage (and cost in terms of tax expenditures) of the IP boxes. For instance, Evers et al. (2014) find that the treatment of expenses relating to IP income is generally more decisive for the effective tax burden than the nominal IP Box tax rate. The treatment of expenses can be so generous that IP Boxes provide negative effective tax rates. In these cases unprofitable investment projects are subsidised by the patent box regime. It is also important to note that other elements of the tax system need to be in place to make such schemes beneficial for tax-planning purposes, namely an extensive network of bilateral treaties, weak CFC legislation, flexible transfer pricing rules and flexibility of the tax administration (e.g. advance rulings). In addition, some countries offer standard corporate tax rates below the tax advantage offered by a patent box and could be more attractive for companies that prefer to book their full profits in such jurisdictions.

In the next section, we examine the fifth important characteristic of patents, the possible imposition of development conditions.

\footnotetext{
${ }^{16}$ Embedded royalties also exist in broader patent boxes such as in Luxembourg, Liechtenstein and Nidwalden canton in Switzerland.
} 


\subsection{Patent Boxes and the link with local $R \& D$}

Current patent boxes approach the question of the link with underlying research activity thanks to which an IP right originated - in different ways. In half of the cases considered in this paper, the patent boxes do not require any development work by the taxpaying company in question. Patent boxes in The Netherlands, Belgium, the United Kingdom, Ireland (up to 2010), Spain, Portugal and China contain(ed) provisions specifying the link with the underlying research activity. ${ }^{17}$ In the EU, this is usually done in the form of a development condition that requires at least part of the patent to be developed by the beneficiary corporate group within the Single Market. However, these conditions differ in their definition and strength. For instance, the Belgian patent box requires that the qualifying patent shall have been developed fully or partially by the taxpaying company in an $R \& D$ centre that qualifies as a branch of activity. In the Netherlands, the patent box applies to intangible assets that the company has developed itself. It also covers intangible assets that are in large part the result of R\&D work, conditional on the taxpaying company receiving a declaration from the Dutch Research Agency (Schellekens, 2013). This declaration in turn links the R\&D activity with the use of the Dutch payroll deduction scheme for researchers. Under the UK patent box a company or group must have performed qualifying development in relation to the IP right, and the rules include provisions against full outsourcing (HMRC, 2010). Nevertheless, an additional 'active ownership condition' potentially limits the constraining aspect of the development condition. In such case, another company within a group could have fully developed the IP right, while the company that pays tax in the UK actively manages the IP portfolio.

Generally, development conditions often contain qualitative terms such as 'substantial' or 'significant' work that are open to interpretation and have to be assessed on a case-by-case basis. ${ }^{18}$ It is also worth mentioning that in the specific case of the EU, its Member States cannot restrict the benefits of $R \& D$ tax incentives to activities performed in their territory as

\footnotetext{
17 China has a preferential rate for new high-technology enterprises, which need to meet a number of requirements to qualify to profit from the rate (e.g. level of R\&D expenses).

18 In our sample, only China applies the territorial restrictions so that most of the related R\&D must be done in China.
} 
this would infringe upon the freedom of establishment and prevent companies from conducting their R\&D elsewhere in the EU. ${ }^{19}$

\section{Empirical strategy}

We base our econometric analysis on a patent count model that links the number of patents registered in a country by company and technology with company-level and patentlevel characteristics. We follow the empirical model proposed by Griffith et al. (2014) and consider the firm's payoff from registering a patent in a specific location as being determined by the following profit function:

$$
\pi_{p, j, t}=\lambda E T R_{j, t}+\alpha \text { patentbox }_{j, t}+\beta_{i} a_{i, j, t}+\gamma_{s} x_{j, t}+\varepsilon_{s, j, t}+\xi_{p, j, t}
$$

Where $p$ stands for the specific patent being considered, $i$ indicates ideas to which this specific patent belongs to, $s$ indicates the industry category to which the firm registering this patent belongs, $j$ is the country in which the patent is registered and $t$ is a time indicator. The variable ETR stands for the effective tax rate, that is the statutory CIT rate minus, when applicable, the tax rebate granted to income-related patents. We want, however, to account separately for the effect of patent boxes, separating the tax reduction linked to the existence of a patent box regime $(T)$ from the non-tax aspects of patent boxes $(N T)$, which define the conditions under which these tax rebates apply. By accounting separately for the tax and nontax aspects of patent boxes we thus also consider that patent box regimes can represent an administrative constraint that firms must comply with in order to benefit from the specific tax rebate granted under the patent box regime. The ETR variable in equation (1) can thus be decomposed into the statutory tax rate $C I T$ and the tax effect of the patent box $T$ :

$$
E T R_{j, t}=C I T_{j, t}+T_{j, t}
$$

$T$ will take non-zero values when a patent box regime exists, which we can in turn formally specify as:

$$
\text { patentbox }_{j, t}=f\left(T_{j, t} ; N T_{j, t}\right)
$$

where the tax component is given by $T_{j, t}= \begin{cases}-X_{j, t} & \text { if } d_{j, t}=1 \\ 0_{j, t} & \text { if } d_{j, t}=0\end{cases}$

\footnotetext{
${ }^{19}$ See Baxter and Fournier European Court of Justice cases, C-254/97 and C-39/04.
} 
with $X_{i, t}>0$ being the tax rebate, in percentage points, granted under a patent box regime applying in country $j$, and $d_{j, t}$ being a dummy variable indicating the existence or absence of a patent box regime in a given country $j$ and year $t$.

The non-tax effect of patent boxes is given by $N T_{j, t}= \begin{cases}1 & \text { if } d_{j, t}=1 \\ 0 & \text { if } d_{j, t}=0\end{cases}$

Hence this non-tax component controls for other-than-tax characteristics of the patent box that may affect the number of patents registered in a country where a patent box regime applies. Replacing the ETR and patentbox variables of equation (1) by its components defined in equations (2)-(5) we obtain the following alternative specification:

$$
\pi_{p, j, t}=\lambda C I T_{j, t}+\alpha T_{j, t}+\phi N T_{j, t}+\beta_{i} a_{i, j, t}+\gamma_{s} x_{j, t}+\varepsilon_{s, j, t}
$$

The specification (1') decomposes the full effect of a specific patent box regime, including the tax advantage $(T)$ and the non-tax patent box component $(N T)$, for a given level of CIT. Equation (1') can be used to analyse the extent to which the tax advantage is large enough to compensate firms for the compliance and administrative costs they must sustain to benefit from this advantage. We can also further decompose the non-tax component (NT) into the effects of the individual characteristics of patent boxes described earlier.

The other control variables included in our estimating equation are the research activity related to idea $i$ being conducted in country $j$ where the patent is being registered $\left(a_{i j}\right)$, as well as a set of control variables measuring the research level of technological activity in country $j$ (represented by the total business R\&D in percentage of gross domestic product, GDP), the size of the local market (represented by the log of GDP) and the strength of the IP protection in country $j$.

In our basic specification, we use a negative binomial logit. The reason for using such an approach is the nature of our data and the large number of potential locations observed. This large number of potential locations in particular implies a large number of zeros in our data, which leads to the well-known problem of over-dispersion (see Rabe-Hesketh and Skrondal, 2012). Hence, in order to account for this over-dispersion, we take advantage of the fact that the firm's size, proxied by the total number of employees, is often directly correlated with the probability of a given firm to register a patent. We use this employment variable as exposure variable, assuming that, the larger the size of the company, the higher the probability for this firm to register a patent. We next also consider a mixed negative binomial model in order to account for unobserved heterogeneity and to estimate fixed and random 
effects on the effective tax variable, which reflects the fact that firms do not behave similarly to fiscal conditions. ${ }^{20}$

\section{Data description}

This paper uses the patent applications of world corporate R\&D investors in 33 different countries over the period 2000-2011. ${ }^{21}$ The analysis is based on the top 2,000 worldwide corporate R\&D investors as reported by the EU Industrial R\&D Scoreboard (European Commission, 2013), which ranks the companies that invested the largest amounts of R\&D in 2012. Alltogether, these companies accounted for about $90 \%$ of global business R\&D spending. ${ }^{22}$

The Scoreboard data are drawn from the latest available company accounts reported in the ORBIS database as provided by Bureau Van Dijk Electronic Publishing. ORBIS contains ownership and balance-sheet accounting and financial information about firms located worldwide. The patents filed by these companies at the European Patent Office (EPO) are from the Patstat ${ }^{23}$ database in the framework of a JRC-OECD joint project (see Dernis et al., 2015). This project has carried out a matching on a by-country basis using a series of string-matching algorithms contained in the Imalinker system (Idener Multi Algorithm Linker) developed for the OECD by IDENER, Seville, 2013. ${ }^{24}$

The characteristics of innovations vary across sectors and so does the influence of taxation on the patent location choices, as discussed in section 2.1. Therefore, we adopt a sectoral approach to our regressions. In particular, we identify three sectors of interest: the car industry (ICB code 3350), the ICT industry (ICB code 9500) and the pharmaceutical industry (ICB code 4570), together with their subsectors. Patent applications pertain to

\footnotetext{
${ }^{20}$ In doing so we also check whether our main results hold when using a specification including random effects, as in Griffith et al. (2014).

${ }^{21}$ Data for 2012 were also available at the time of writing of this paper although they did not yet cover the full year. The use of these data would have resulted in unbalanced exposure across the year and could have potentially biased our results.

${ }^{22}$ The EU Industrial R\&D Investment Scoreboard sample is assembled by the Joint Research Centre of the European Commission. For more information on the sample of firms included in the R\&D Scoreboard, see http://iri.jrc.ec.europa.eu/scoreboard.html.

${ }^{23}$ PATSTAT is the European Patent Office's Worldwide Patent Statistical Database, which contains data about 70 million applications from more than 80 countries. See more details at http://www.epo.org.

${ }^{24}$ Overall, in 2012 the top R\&D investors controlled more than 500,000 subsidiaries (defined as firms more than $50 \%$ owned by the parent), including 'branches', which account for about $34 \%$ of all subsidiaries. Patent applications have been aggregated at the group level. A more extensive description of the approach used to perform the matching between Orbis and PATSTAT can be found in Dernis et al. (2015). For a description of Imalinker, see http://www.idener.es/?portfolio=imalinker.
} 
different technological fields. ${ }^{25}$ Globally, in our full sample, chemistry counts for close to a quarter of all applications, very closely followed by electrical engineering; about a fifth of all applications are related to mechanical engineering and instruments. The remainder, 'other fields' counts for the remaining $9 \%$ of patent applications. Their repartition, however, differs widely across sectors. As shown in table 3, each sector focusses mainly on one specific technology field, but not exclusively. In the car industry, $63.98 \%$ of the 88,826 patent applications are related to mechanical engineering technology. In the ICT sector, electrical engineering accounts for $81 \%$ of all applications and in the pharmaceutical sector, chemistry has the lion's share with $79.5 \%$. These differences justify a sectoral approach. ${ }^{26}$

In our regressions, the Statutory corporate income tax is, unsurprisingly, the statutory CIT rate applicable in the country, including surcharges. We logically expect this variable to have a negative and significant effect on the number of patents. Next, Tax advantage in patent box $(T)$ defined by equation 3 is a variable capturing the tax reduction offered under the patent box regime compared with the normal CIT rate. Hence, we expect this later variable to exert a positive and significant effect on the number of patent applications. Finally, the Non-tax effect of patent boxes (NT) is a dummy taking the value 1 when a patent box regime is in force in the potential country of patent application. Combined in the same regression with the Tax advantage in patent box $(T)$, the dummy variable (NT) captures all the non-tax (positive or negative) influence of patent boxes on patent applications. Starting with only two regimes in 2000 (France and Ireland), the number of patent boxes has increased and reached 10 by 2011 (Belgium, China, France, Hungary, Liechtenstein, Luxembourg, Malta, Switzerland, Spain and The Netherlands).

Other variables have influence on patent applications. We control for the size of the market measured by the log of GDP (in Euros) of the country of potential application by the variable GDP level. The innovation potential of the country is captured by private business R\&D expenditures in percentage of GDP, Business $R \& D / G D P$. A high level of IP protection in the legislation is captured by the index variable IP protection. For this variable, we take a widely used index developed by Ginarte and Park (1997) and subsequently updated by Park (2008). Finally, Real Research Activity measures whether or not any of the inventors of a

\footnotetext{
${ }^{25}$ The Industry Classification Benchmark (ICB) is a classification widely used by stock exchanges such as the NASDAQ and the NYSE.

${ }^{26}$ Moreover, to ensure consistency, our econometric estimations are run considering only the patents registered under the most frequent technology by sector.
} 
given patent reside in the country where the patent is registered according to the Patstat database. Since we use a count model, the Real Research Activity is measured by the number of patents where at least one of the inventors resides in the country where the patent was registered, as a percentage of the total number of patents registered in that country by a given firm. All four controls variables also used by Griffith et al (2014), are expected to exert a positive effect on patent applications.

Table 4 provides summary statistics on the dependent and exogenous variables for the estimation samples used to run our base regressions. The average value of the patent count is nearly 20 times lower than its standard deviation in all three sectors, illustrating the skewness of the dependent variable. The explanatory variables display similar means and standard deviations across sectors as these are country-specific. The level of IP protection, GDP and business R\&D also display low variability compared with the tax advantage and non-tax patent box effects, reflecting the fact that, over the period considered, countries have increasingly used patent boxes, thereby reducing their effective CIT rate to attract patenting activities.

\section{Results}

We first run our basic regression separately for the three sectors of interest. The results are reported in Table 5. In the sequel we discuss our basic results of estimating the effect of the patent box regimes and the related fiscal advantage on the number of patents for a set of 33 countries. We then extend our analysis to the influence of patent quality and patent box characteristics. Finally, we provide results on the influence of patent boxes on local research activity, highlighting in particular the effects of patent box characteristics, which define the conditions under which patent box regimes apply.

\subsection{Patent boxes and the fiscal advantage of patent box regimes}

Table 5 reports separate results for each of the sectors. All regressions contain country and time fixed effects, on top of our four control variables (GDP level, Business $R \& D / G D P$, IP protection and Real Research Activity). Given that our dependent variable is defined on a country-level basis and that the patent count variable is defined at firm level, we also cluster our observation at the country level, following Moulton (1990). IP protection and Real Research Activity both have, as expected, a large positive and significant effect on patent 
location. The level of business R\&D in relation to GDP seems to have no significant effect, appearing at best small and only significant at the $10 \%$ level in only a few regressions. Finally, the log of GDP has contrasted effects. It appears to exert a strong and significant positive effect for the pharmaceutical sector and to some extent for ICT. The effect is, however, mainly negative for the car industry, which may be due to the absence of US leadership and a high geographical concentration of patents, ${ }^{27}$ despite the presence of country dummies.

In all three sectors, the effective CIT rate exerts the expected negative effect on the location of patents as shown in column 1 . This effect is always significant at the $1 \%$ level. In the first three columns, we estimate the model with the effective CIT rate, i.e. the tax rate incorporating the effect of patent boxes whenever these apply in a given country/year. As in the previous literature, we find that this effective CIT rate has a negative and significant effect on the probability of choosing a specific country for registering a patent. The (unreported) marginal effects on the estimated coefficients are equal to $-13.1 \%,-1.5 \%$ and $5.4 \%$ for the pharmaceutical, ICT and car industries respectively.

Our approach allows us to go one step further and decompose the tax effects into the effects of the standard CIT rate and the effect of the patent box tax benefit. The tax advantage offered by the patent box regime comes with a significant positive effect in all three regressions 4-6. This is the expected effect. However, to determine the full effect of patent boxes one should also account for the non-tax characteristics of patent boxes implemented in each country that grants a tax rebate on IP-related revenues. These come out as negative and highly significant, potentially reflecting the compliance and administrative costs linked to patent boxes. When calculating the marginal effects in these regressions, we find that, for each percentage point reduction in the CIT rate thanks to the patent box, the likelihood of registering a patent in the country concerned will rise by $10.4 \%, 7.6 \%$ and $17.5 \%$ for the pharmaceutical, ICT and car industries respectively. The effect of patent boxes is therefore economically significant.

To determine the global effect of patent boxes on patents location, it is important to recall that in non-linear models - such as the negative binomial used here - the marginal effects are sensitive to the baseline values given to all variables. This is particularly relevant

\footnotetext{
${ }^{27}$ In our sample, the top three patent locations for the car industry (DE, JP, US) represent $83.0 \%$ of cases, compared to $69.7 \%$ in the pharmaceutical sector and $66.7 \%$ in the ICT sector.
} 
in our case given that the effect of a patent box regime mainly depends on the tax rebate offered, which is itself often a percentage of the CIT rate and on the conditions under which this tax rebate applies, i.e. the non-tax patent box characteristics. To account for the full effect of patent box regimes we need to consider both components together. As just mentioned, marginal effects are estimated by default at the average value of all control variables, including the tax variables. However, the baseline value of a control for a specific category of observations frequently differs from the baseline value for the entire sample. For example, the average tax advantage of patent boxes is in reality about 17 percentage points but it drops to 2.7 percentage points when we consider the whole sample, including observations without a patent box, for which this advantage is therefore zero. The average value of 2.7 percentage points is even well below the observed lowest tax advantage in our sample (bar the zeros), that is 8.8 percentage points. In addition, a company may choose to set up a subsidiary in a given country primarily to reduce its overall tax bill by shifting patent registration there, but it might also consider the level of the CIT rate applying to revenues other than patents. It is therefore important to consider alternative cases where the tax reduction and the starting level of the CIT rate depart from their average value.

As can be seen in columns 4-6 of Table 5 the coefficient of the non-tax patent box characteristics variable is negative and significant. This variable measures the effect of treating firms differently through a patent box regime without changing the average tax rate. Estimating this effect at the average value of the explanatory variable for the whole sample gives little information, since the very existence of a patent box regime implies that a fiscal advantage is offered. Hence, the marginal effect of the tax advantage of the patent should be calculated at the average value for observations for which a patent box is in place and not at the average value for the whole sample.

A more general concern about the estimation of marginal effects of interaction effects in non-linear model lies in the fact that the marginal effect cannot be directly determined by the first derivative of the expected value of the dependent variable with respect to the interaction term. The marginal effect should be instead calculated as the cross partial derivative of the dependent variable with respect to each interacted variable separately in order to interpret it correctly. A very practical solution is to calculate the incidence ratio. The marginal effect of the interaction term between the tax rebate and the dummy variable $d_{j, t}$, can be interpreted directly as a measure of the differential impact of the tax rebate due to the 
presence of a patent box regime. Calculating the incidence ratio, one can infer the marginal effects of multiplicative terms directly. ${ }^{28}$

Using this approach, we also look into the effect of predicted change in the number of patent at various levels of corporate tax rebate in the patent box regimes at average (i.e. $32 \%$ ) and high (i.e. 51.6\%) levels of the CIT rate. The results of these simulations are reported in Figure 2. We consider tax rebates up to 30 percentage points. As can be seen in this case, the predicted change in the number of patents registered increases substantially once the tax advantage reaches high levels, i.e. beyond $20 \%$ and it does so at growing rates. Considering average values of the tax rebate $(17 \%)$ and the observed values of the patent count by sector/year, we find that the predicted change in the number of patent for the average CIT rate varies between the $4.4 \%$ for the pharmaceutical industry and the $31.8 \%$ for the ICT one. Interestingly, the larger marginal impact is found for average rather than high starting CIT values, reflecting the fact that, for the former, the relative change in CIT brought by the patent box is often greater in relative terms. In addition, the ICT sector appears to benefit the most from patent boxes in the case of large corporate tax rebates, followed by the car industry. The difference between the high and average tax scenarios is also most marked for the car industry. By contrast, the percentage change in the number of patents registered, although also positive and larger in the average CIT scenario, is also sensibly lower in the case of the pharmaceutical industry.

As a robustness check, we also estimate our model by analysing whether or not firms could respond heterogeneously to the tax advantage offered by patent boxes. We therefore run the mixed-effects version of the negative binomial model by estimating the random effects. The last three columns of Table 5 report the results of the mixed negative binomial estimation with a random effect estimated for the tax advantage variable. These results are qualitatively similar to the ones obtained with the negative binomial model. We now find a

28 In particular the marginal effects of an interaction term provided by the statistical software will be the marginal effect of the interaction term calculated at the average sample value for both elements of the interaction on the expected value of the number of patents $\frac{\partial \mathrm{E}(\# \text { patents) }}{\partial(\mathrm{dj}, \mathrm{t} * \mathrm{~T})}$ where $d_{j, t}$ stands for the patent box dummy variable and $T$ is the tax advantage in the patent box regime. In reality, the average tax advantage conditional on having a patent box is higher than for the total sample (which includes the cases for which there is no patent box). Hence, the marginal effect is not calculated at the right reference point. We are instead interested in the marginal effect of the patent box on the marginal effect of the tax advantage on the expected number of patents, that is $\partial\left(\frac{\partial \mathrm{E}(\# \text { patents) }}{\partial \mathrm{T}}\right) / \partial \mathrm{dj}, \mathrm{t}$. We are particularly thankful to Marteen Buis for very helpful discussion on this point. 
slightly lower coefficient for the tax advantage in the pharmaceutical industry and a significantly higher coefficient in the ICT and car industries. More interestingly, the random term on the tax advantage displays a significant coefficient in the ICT and car industry. This coefficient is not significantly different from zero in the pharmaceutical industry, however. The random components are, nonetheless small, indicating that, although firms may indeed be heterogeneous in terms of their reaction to tax rebates on patent boxes, this heterogeneity is small compared with the average effect of patent boxes (i.e. the so-called fixed effect in the mixed-model terminology). The fact that our regressions are estimated for each sector separately can explain this result because, within each sector, firms are more homogeneous in terms of technologies used and importance of the fiscal dimension for research activities. In the extensions of our empirical analysis presented in the following sections, we will use the negative binomial model without the random term, which is also computationally less demanding, since the model with the random effect does not appear to modify our results significantly.

\subsection{Patent quality}

Innovation outcome distributions are highly skewed with major innovations capturing the lion's share of value creation (Scherer and Harhoff, 2000). Patent quality can serve as a proxy for innovations with high earning potential, the holy grail of innovation policy. The role played by ideas and patent quality is therefore quite fundamental in the analysis of patent boxes. The motives for different patent registration choices are likely to be correlated within ideas, and so is the potential influence of tax determinants, since firms are likely to decide on the geographical registration of their patent portfolio strategically, depending on the market potential of new ideas embedded in patents. Griffith et al. (2014) use a group variable based on the simultaneity between industry and the network of inventors of patents registered by a single firm to identify idea membership. Such a measure could, nevertheless, be regarded as somewhat restrictive, since it excludes patents registered by different firms but relating to the same idea or invention, as well as patents relating to the same idea or invention but registered at different times. There are also two reasons for using an alternative measure of patent quality. First, competing firms are also likely to compete for similar ideas. Second, firms may attempt to protect ideas or to generate revenues from a given idea by registering patents at successive times. To account for these possibilities, we use instead an indicator variable based on the information provided by the International Patent Documentation, i.e. the socalled INPADOC family group, produced by the European Patent Office. The INPADOC 
family groups indicate if a given patent registration corresponds to the same priority and invention. Using information based on INPADOC membership is likely to provide an accurate measure of the quality of the patent given that it is not exclusive in terms of the time of registration and firm ownership of the patent. We defined high-quality patents as those belonging to the top quartile by sector in terms of INPADOC family size. In line with our approach, patent's family size is also a preferred quality measure of Böhm et al (2014). In Figure 2, we report the weighted average of the statutory and effective tax rates (i.e. including the patent box rebate whenever in place), using as weight the total number of patents registered. As one can see, high-quality patents tend to be located in countries with lower corporate taxation and with a larger gap between the standard CIT rate and the effective tax rate. This descriptive evidence thus suggests that firms have exploited the tax advantage offered by patent boxes especially for high-quality patents.

To confirm these results, we have run regressions separately for high-quality patents, defined as patents belonging to the top quartile in terms of patent family size as defined above, and compared the results with the regressions covering the remaining patents. The results of these additional regressions are reported in Table 6. The effects of both the statutory CIT rate and the tax advantage in the patent box regime are different between the two groups of regression. The coefficients obtained for the statutory CIT rate are lower for high-quality patents, and the tax advantage coefficients are always larger, although not always clearly so. Since these additional regressions are run over different sample sizes, we have tested the significance of the difference in the coefficients estimated using a Wald test. The results of these tests are reported in the last row of Table 5 showing that the null hypothesis of equal coefficients can be rejected at $99 \%$ confidence levels. These results therefore suggest that high-quality patents tend to be significantly more sensitive to taxes.

\subsection{Patent box characteristics}

Next, we are interested in whether or not the specific characteristics of patent boxes have an effect on patent location and whether these effects vary across sectors. Given the high multicollinearity in some of the patent box characteristics reported in Table 2 not all these characteristics were included in the regression. To test the effects of characteristics, we have identified five dimensions of patent boxes and we add dummy variables reflecting these specific features of the patents as described in Tables 1 and 2 . These regressions are run conditionally to the existence of the patent box regime, i.e. they are run for countries/years in 
which a patent box regime was in place. In doing, so we can interpret our estimates in terms of marginal effect of a given patent box characteristic for a baseline average effect of the patent box as presented in Table 5 .

The first set of characteristics considered are dummy variables respectively for whether or not acquired patents, embedded royalties and existing patents (i.e. patents prior to the creation of the patent box) qualify for the tax advantages of patent boxes. The results of these regressions are reported in the first three columns of Tables 7-9 for each sector separately. We focus on the coefficient obtained on the tax advantage interacted with the specific patent box characteristic without making any inference on the separate dummy variables, since, as discussed earlier, such discussion is best made for other than average values of the control variables. We find the tax advantage in the acquired patents characteristics to be positive and significant in all three sectors. The tax advantage in the embedded royalties is positive and significant for the ICT and car industries, while the existing patents condition is positive and significant for the pharmaceutical and car industries. Taken at the average value of the tax advantage, we find that these characteristics still exert a positive effect on patent location. We also find that for the car industry the tax advantage in the existing patents condition is negative and significant, which might reflect the dominant role played by large car producers with high patenting activity, such as Germany and Japan, where strategic market considerations might prevail over tax advantage when deciding about the location of a patent registration.

Next, in regressions 4 of Tables 7-9, we look at the effect of having patent boxes offering a tax advantage to a larger range of rights than just patents (see Table 1 for details). The tax advantage of these patents is positive and significant for all three sectors with large coefficients. Finally, in regressions 5 of the tables, we consider the role played by development conditions whereby countries grant tax rebate conditional on R\&D activities being developed within the country. Controlling for the development conditions dummy variable makes the tax advantage to be insignificant in the ICT and Car sectors, while it makes it negative and significant for the Pharmaceutical sector. The effect of development condition thus appears to be rather heterogeneous across sectors. Compared with the general tax effect of patent boxes, such development conditions does not seem to affect the number of patents registered in the ICT and Car industries and decreases it in the Pharmaceutical industry. 


\subsection{Effects of patent boxes on real activity}

We now consider the interaction between patent box regimes and local innovative activity. In particular, we are interested in testing two arguments put forward in the patent box debate: $(i)$ to what extent the tax rebate granted by a patent box is effectively promoting local inventorship, as this is an often advocated justification for granting preferential tax treatment; and (ii) the effectiveness and strength of development conditions in ensuring that the link between the tax rebate and the underlying research activities is effectively delivering. We test the influence of patent box regimes and development conditions on local inventorship by considering whether the patent registration leads to an increase in the number of inventors in the country of registration while the number of inventors in the parent country decreases or remains constant. This indicator is used as dependent variable whereby a value equal to 1 would indicate that the real activity has been actually moved to the patent box country. Indeed, although we do not observe whether the inventors actually move from one country to another, we can reasonably assume that such simultaneous rise and fall in the number of inventors in two different parts of the (company) group indicates an inventor shift. These regressions are performed at the company-level. Given that in this case we have a binary variable taking values of 1 or 0 , we estimate our model through logistic regressions. As control variables, we use the same as the previous specifications with two exceptions. On the one hand, we first remove the real activity variable as this variable could be endogenous in this specification. We then check if including this dummy back in the regression alters our results. On the other hand, we include a binary variable indicating the presence of development conditions in the patent box regime.

The results of these estimations are reported in Table 10. Columns 1-3 provide the results from the logistic regressions on the probability of actually performing an inventor shift without controlling for the real activity variable. Columns 4-6 provide the results of the specification controlling for the real activity variables. Results are similar in both specifications: the CIT and tax advantage in the patent box regime display negative and significant coefficients with similar values in each specification. These results suggest that the tax advantage linked to the patent box does decrease the probability of moving inventors to the patent box country. The fiscal advantage of patent boxes thus tends to deter local inventorship rather than favor it. These results suggest that firms could be principally interested in the tax rebate when registering a patent in a country with a patent box regime, rather than in setting (extending) $R \& D$ facilities there. However, the presence of a 
development condition has a strong effect in reversing this tendency. Countries including a specific local development condition have a higher probability of experiencing an inventor shift in their favor, as reflected by the positive and significant coefficient attached to the development condition variable. This result also holds independently of controlling for the local research activity variable.

The tax advantage and the development conditions thus tend to have opposite effects. Their combined impact on inventor shifting is likely to depend on the corporate tax rebate offered and the specific firm/sector patenting activities. To quantify the importance of each of these elements we proceed to simulate the predicted probability of inventor shifting in the presence and absence of R\&D development conditions for each sector of activity and considering different levels of tax advantage. Figure 4 illustrates the results of these simulations whereby the marginal effect of development condition is calculated as the difference between the predicted probability of having an inventor shift for countries with a development condition and the same probability for countries that do not include such a condition in their patent box regimes. We base our simulation on the specification including the Real research activity variable (unreported results without this variable display very similar results). At the sample average tax rebate (17.8\%) indicated by the discontinuous vertical line in Figure 5, the probability to observe inventor shift between the home and the host country increase by order of $60 \%, 45 \%$ and $30 \%$, for the car, pharmaceutical and ICT industries respectively. The overall impact of development conditions is always positive in all scenarios of tax rebates: it varies between $37.6 \%$ and $48.4 \%$ for the car industry, between $34.1 \%$ and $43.9 \%$ for the pharmaceutical industry and between $19.2 \%$ and $32.2 \%$ for the ICT sector. It interesting to note that the maximum impact of the local development conditions is reached at lower values of the tax rebates, i.e. at $12 \%$ for the car industry, $9 \%$ for pharmaceutical and at $1 \%$ for the ICT sector. These results would suggest that the optimum tax rebate is likely to be lower than the actual average tax rebate in presence of $R \& D$ development conditions. Under the assumption that a government objective is to minimise the fiscal loss and to maximise the local R\&D impact, our results would indicate that, when development conditions are included under a patent box regime, the tax breaks offered tend on average to be slightly larger than the optimal level. 


\section{Conclusions}

This paper analyses how the implementation of patent boxes affects the patent-filing strategies of top corporate R\&D investors across countries. For this, we use a recent and rich firm-level dataset for the 2000-2011 period on the top 2,000 corporate R\&D investors worldwide, considering their ownership structure, and analyse the determinants of patent registration across a large sample of countries. For the first time, we disentangle the effect of three key characteristics of patent boxes: the corporate income taxation; the tax advantage of registering patents in a patent box country; and other characteristics of the patent boxes that define both their scope (i.e. the tax base) and non-fiscal characteristics such as local R\&D development conditionality. Patent boxes exert a strong effect on attracting patents, mostly due to the specific favourable tax treatment that they bring about. However, this effect varies across sectors and with the specific characteristics of the patents. High-quality patents are shown to be more influenced in their location choices by the tax advantage offered by patent boxes than patents of lower quality. The possibility to grant the patent box tax regime to patents that have been acquired, existed previously or contain embedded royalties seems to make patent location even more sensitive to the tax advantages offered by patent boxes. The same can be said of patent boxes broadening their scope to other rights such as trademarks, design and models, copyrights or domain names. Our results also suggest that in the majority of cases, the existence of a patent box regime incentivises multinationals to shift the location of their patents without a corresponding growth in the number of inventors or a relocation of R\&D activities. We find that the size of the tax advantage is negatively correlated with the local R\&D. This suggests that the effects of patent boxes are mainly of a tax nature.

An interesting development of patent boxes concerns the possibility of imposing development conditions for the patent to qualify for the advantageous tax regime. This is the case in several countries. These conditions provide a proxy for the possible effect of conditionality clause discussed at the EU and OECD, i.e. the so-called nexus approach. Our results show that such specific condition appears to dampen the dominant effects of the tax advantage of the patent box regime on patent locations while encouraging local inventorship. In addition, our simulation suggests that the optimal preferential tax treatment offered to patent registration could be lower than its current average value (17.8\%). This would optimise the impact of patent box regimes on local R\&D activity, provided that such development conditions are in place. Future challenges, such as the need to reach a common 
agreement on the definition and measurement of $R \& D$ activities as well as their link to patenting activities, will of course emerge in case such clauses are implemented.

Patent boxes are a relatively recent development among the tools offered to companies to boost R\&D activities. They have been criticised for offering additional tax advantages to income already profiting from an IP protection and having potentially little effect on the level of R\&D. Their development has raised concerns over the fact that they could exert a significant effect on patent location without any change in the real research activity, targeting only the tax benefits. Our results confirm these fears, with the tax attractiveness of patent boxes being greater the broader their scope. Recent debates on the potentially harmful consequences of patent boxes have addressed the possibility of linking the advantages of patent to the requirement of a real research activity by the taxpayer that receives tax benefits. Our results suggest that it has the potential to decrease the still dominant tax effects of patent boxes on patent location and to raise the level of local inventorship. The nexus approach therefore offers some potential to mitigate the role of patent boxes as new tax competition tools. 


\section{References}

Arundel, A. (2001), The relative effectiveness of patents and secrecy for appropriation, Research Policy, 30(4): 611-624.

Balasubramanian, N. and J. Sivadasan (2011), What Happens When Firms Patent? New Evidence from U.S. Economic Census Data, The Review of Economics and Statistics, 93(1): 126-146.

Becker, B. and N. Pain (2008), What Determines Industrial R\&D Expenditure in the UK?. Manchester School, 76(1): 66-87.

Becker, J. and C. Fuest, 2007. Quality versus quantity - the composition effect of corporate taxation on foreign direct investment. CESifo Working Paper Series 2126.

Becker, J., Fuest, C. and N. Riedel (2012), Corporate Tax Effects on the Quality and Quantity of FDI, European Economic Review, 56(8): 1495-1511.

Blind, K., Edler J., Frietsch, R., Schmoch, U. (2006). Motives to patent: Empirical evidence from Germany, Research Policy 35: 655-672.

Bloom, N., R. Griffith and J. van Reenen (2002), Do R\&D Tax Credits Work? Evidence from a Panel of Countries 1979-1997, Journal of Public Economics 85: 1-31.

Bloom, N. and R. Griffith (2001), The Internationalisation of UK R\&D, Fiscal Studies 22 (3): 337-355.

Böhm, T., Karkinsky, T. and N. Riedel (2014), The Impact of Corporate Taxes on R\&D and Patent Holdings, mimeo.

Buettner, T. and M. Ruf (2007), Tax Incentives and the Location of FDI: Evidence from a Panel of German Multinationals, International Tax and Public Finance 14: 151-164.

Council of the European Union, Code of Conduct (Business Taxation)- Draft Report to the Council, doc 16100/14, FISC 216, ECOFIN 1105,2014.

CPB (2015), "Study on R\&D Tax Incentives", Taxation Papers, 52.

Dernis H., Dosso M., Hervás F., Millot V., Squicciarini M. and Vezzani A. (2015). World Corporate Top R\&D Investors: Innovation and IP bundles. A JRC and OECD common report. Luxembourg: Publications Office of the European Union.

Desai, M. A. and J. R. Hines (2002), Expectations and Expatriations: Tracing the Causes and Consequences of Corporate Inversions, National Tax Journal, 55(3): 409-40.

Devereux, M.P., Lockwood, B. and M. Redoano (2008), Do Countries Compete over Corporate Tax Rates?, European Economic Review, 92(5-6): 1210-1235.

Dischinger, M., and Riedel, N. (2011), Corporate taxes and the location of intangible assets within multinational firms. Journal of Public Economics 95: 691-707.

Ernst, C. and C. Spengel (2011), Taxation, R\&D Tax Incentives and Patent Application in Europe, Centre for European Economic Research, ZEW Discussion Paper, No.11-024. 
Ernst, C., K. Richter and N. Riedel (2014): Corporate taxation and the quality of research and development, International Tax and Public Finance 1-26.

European Commission (2013). The 2013 EU Industrial R\&D Investment Scoreboard, Luxembourg: Publications Office of the European Union.

European Commission (2014a), EU R\&D Scoreboard, The 2014 EU Industrial $R \& D$ investment scoreboard, Institute for Prospective Technological Studies, Joint Research Centre, European Commission.

European Commission (2014b), Taxation Trends in the EU, Brussels.

Evers, L., Miller, H. and C. Spengel (2014), Intellectual Property Box Regimes: Effective Tax Rates and Tax Policy Considerations, International Tax and Public Finance, 1-29.

Financial Times, 12 March 2014, Tanya Powley: "Aerospace and automotive are UK manufacturing's star performers".

Financial Times, 29 April, 2014, Vanessa Houlder, "Patent box holds key of Pfizer-AZ deal's attraction".

Fuest, C., Spengel, C., Finke, K., Heckemeyer, J.H. and H. Nusser (2013), Profit Shifting and "Aggressive" Tax Planning by Multinational Firms: Issues and Options for Reform, World Tax Journal (3).

Garnier, G. , Gyorgy, E., Heineken, K, Mathe, M., Puglisi, L., Rua, S., Skonieczna, A. and A. Van Mierlo, (2014) A Wind of Change? Reforms of Tax Systems since the Launch of Europe2020, Reflets et Perspectives de la Vie Economique, 53(2): 75-111.

Ginarte, J.C., Park,W.G., (1997). "Determinants of patent rights: a cross- national study", Research Policy 26: 283-301.

Greenhalgh and Rogers. (2010). Innovation, Intellectual Property, and Economic Growth. Princeton University Press.

Griffith, G., H. Miller and M. O'Connell (2014), "Ownership of intellectual property and corporate taxation", Journal of Public Economics 112: 12-23.

Hall, B. H. and D. Harhoff (2012), Recent Research on the Economics of Patents, Annual Review of Economics, 4(1): 541-565.

Hall, B. H., Lotti, F. and J. Mairesse (2013), Evidence on the impact of R\&D and ICT investments on innovation and productivity in Italian firms, Economics of Innovation and New Technology, 22(3): 300-328.

Hall, B. H., Lotti, F. and J. Mairesse (2014), The Choice between Formal and Informal Intellectual Property: A Review, Journal of Economic Literature 2014, 52(2): 375-423.

Hanel, P. (2008), "The use of intellectual property rights an innovation by manufacturing firms in Canada”, Economics of Innovation and New Technologies, 17: 285-309.

Scherer, F. M, Harhoff, D. (2000). Technology policy for a world of skew-distributed outcomes, Research Policy, 29: 559-566. 
Kamran, L (2014). Patent Laws, Product Life-Cycle Lengths, and Multinational Activity. American Economic Review 2014, 104(7): 1979-2013.

Karkinsky, T. and N. Riedel (2012), Corporate Taxation and the Location of Patents within Multinational Firms, Journal of International Economics, 88(1): 176-185.

Moulton, B. R. (1990). An illustration of a pitfall in estimating the effects of aggregate variables on micro units. The Review of Economics and Statistics, pp. 334-338.

Obuoforibo, B. (2013), The technical aspects of the UK patent box rules, European Taxation, 53(10): 1-11.

OECD (2014), Countering Harmful Tax Practices more Effectively, taking into account Transparency and Substance, OECD/G20 Base Erosion and Profit Shifting Project, Action 5

OECD (2015a), OECD Tax Database.

OECD (2015b) Action 5: Agreement on Modified Nexus Approach for IP Regimes. OECD/G20 Base Erosion and Profit Shifting Project.

Park, W.G. (2008), "International patent protection: 1960-2005", Research Policy: 37(4): 761-766.

Peeters, C. and B. van Pottelsberghe (2006), Innovation strategy and the patenting behavior of firms, Journal of Evolutionary Economics, 16(1): 109-135.

Rabe-Hesketh, S., and A. Skrondal. (2012), Multilevel and Longitudinal Modeling Using Stata. 3rd ed. College Station, TX: Stata Press.

Sanz-Gómez, R., (2015), " The OECD's Nexus Approach to IP Boxes: A European Union Law Perspective", WU International Taxation Research Paper 2015 - 12, Wien University.

Schellekens, M. (2013), The Netherlands as an Innovation Hub: An Appraisal of the Innovation Box Regime. European Taxation, 2013 (Volume 53), No. 10

Siedschlag, I., Smith, D., Turcu, C. and X. Zhang (2013), What determines the location choice of R\&D activities by multinational firms? Research Policy 42: 1420- 143.

Squicciarini, M. and H. Dernis (2013), "A Cross-Country Characterisation of the Patenting Behaviour of Firms based on Matched Firm and Patent Data", OECD Science, Technology and Industry Working Papers 2013/05, Organisation for Economic Cooperation and Development, OECD, Paris.

Van der Made, B. (2014), Update on the EU Code of Conduct Group, International Tax Review, 26 February 2014, http://www.internationaltaxreview.com/Article/3313023/EUUpdate-on-the-EU-Code-of-Conduct-Group-Business-Taxation.html

Van der Made, B. (2015), Update on the EU Code of Conduct Group, International Tax Review, 24 February 2015, http://www.internationaltaxreview.com/Article/3430573/EUUpdate-on-patent-boxes-and-the-EU-Code-of-Conduct-Group-Business-Taxation.html

Wilson, J.D. (1986), A theory of interregional tax competition, Journal of Urban Economics, 19(3): 296-315. 
Wilson, J.D. (2009), Beggar Thy Neighbor? The In-State, Out-of-State, and Aggregate Effects of R\&D Tax Credits, The Review of Economics and Statistics 91(2): 431-436.

Zodrow, G.R. and P. Mieszkowski (1986), Pigou, Tiebout, property taxation, and the underprovision of local public goods, Journal of Urban Economics, 19(3): 356-370. 
Table 1: Coverage of patent boxes by country in 2014

\begin{tabular}{|c|c|c|c|c|c|c|c|c|c|c|c|c|c|}
\hline & NL & BE & LU & FR & PT & China & UK & ES & HU & MT & $\mathrm{CH}(\mathrm{NW})$ & CY & LI \\
\hline \multicolumn{14}{|c|}{ Patents and associated patent rights } \\
\hline \multicolumn{14}{|l|}{ Trademarks } \\
\hline Designs and models & a) & & & & & & & & & & & & \\
\hline Copyrights & a) c) & & c) & & & c) & & & & d) & & & \\
\hline \multicolumn{14}{|l|}{ Domain names } \\
\hline Trade secrets /know-how & a) & b) & & b) & & & & & & & & & \\
\hline $\begin{array}{l}\text { a) Only if R\&D declaration } \\
\text { b) Know-how (BE)/in dustrial process } \\
\text { c) Only software } \\
\text { d) Only artistic }\end{array}$ & ociated & patents & & & & & Colo & des: & $\begin{array}{l}\text { Yes: } \\
\text { Yes, with } \\
\text { No: }\end{array}$ & estrictions: & & & \\
\hline
\end{tabular}

Sources: European Commission

Table 2: Patent box characteristics

\begin{tabular}{|c|c|c|c|c|c|c|c|c|c|c|c|c|c|c|}
\hline & FR & HU & NL & BE & LU & ES & мT & cY & UK & PT & LI & $\mathrm{CH}$ & IE & China \\
\hline $\begin{array}{l}\text { Top corporate income tax rate (TTR } \\
\text { 2014) }\end{array}$ & 38 & 20.6 & 25 & 34.00 & 29.2 & 30 & 35 & 12.5 & 21 & 31.5 & 12.50 & $\begin{array}{c}8.5 \%(+ \\
6 \%\end{array}$ & 12.5 & 25 \\
\hline $\begin{array}{l}\text { Effective tax rate on patent income } \\
\text { within the patent box (calculated on } \\
\text { top CIT rate with surcharges) }\end{array}$ & $\begin{array}{c}15.5(16.245 \% \\
2011-2015)\end{array}$ & 10.300 & 5.000 & 6.798 & 5.840 & 12.000 & 0.000 & 2.500 & 10.00a) & 15.750 & 2.500 & 8.800 & 0.000 & 15.000 \\
\hline $\begin{array}{l}\text { Year introduced } \\
\text { (changed) }\end{array}$ & 1971 & $\begin{array}{l}2003 \\
(2012)\end{array}$ & $\begin{array}{l}2007 \\
(2010)\end{array}$ & 2007 & 2008 & $\begin{array}{l}2008 \\
(2013)\end{array}$ & 2010 & 2012 & 2013 a) & 2014 & 2011 & 2011 & $\begin{array}{l}1973 \\
(2008)\end{array}$ & 2007 \\
\hline \multicolumn{15}{|l|}{\begin{tabular}{|l|}
$\begin{array}{l}\text { Only patents and rights associated with } \\
\text { patents }\end{array}$ \\
\end{tabular}} \\
\hline \multicolumn{15}{|l|}{ Applicable to existing IP } \\
\hline Applicable to acquired IP & b) & & & c)* & & & & & c) & & & & & \\
\hline Authority granting the IP right & d) & & & d) & & & & & $\left.d^{*}\right)$ & d) & & & & d) \\
\hline \multicolumn{15}{|l|}{ Development condition } \\
\hline Capital gains included? & & f) & & & & e) & & & & & & & & \\
\hline $\begin{array}{l}\text { Income from the sale of innovative } \\
\text { products (embedded royalties) }\end{array}$ & & & & & & & na & & & & & & & \\
\hline $\begin{array}{l}\text { Can R\&D be performed abroad (or } \\
\text { within a group)? }\end{array}$ & & & g) & h) & & j) & & & i) & k) & & & o) & 1) \\
\hline \multicolumn{15}{|l|}{ Cap } \\
\hline $\begin{array}{l}\text { Other major tax reforms that could } \\
\text { affect the location decision }\end{array}$ & $\begin{array}{l}\text { CIR } 2008 \text { CICE } \\
2013 \& 2014\end{array}$ & & & ACE 2006 & & \begin{tabular}{|l|} 
Interest \\
barrier \\
rules \\
$2012 ;$
\end{tabular} & & & \begin{tabular}{|l|l|} 
Gradual \\
decrease in \\
CiT rate \\
from 28\% in \\
2010 to $20 \%$ \\
in 2015
\end{tabular} & \begin{tabular}{|l|} 
Interest \\
barrier rules \\
$2013 ;$ major \\
CIT reform \\
$2013 / 14$
\end{tabular} & & & \begin{tabular}{|l|} 
Abolished \\
2010
\end{tabular} & $\begin{array}{c}\text { Major CIT } \\
\text { reform in } \\
2007\end{array}$ \\
\hline 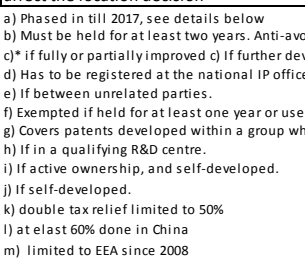 & $\begin{array}{l}\text { oidance rules for intr } \\
\text { veloped and actively } \\
\text { e/d* granted by UKIO } \\
\text { ed to buy other IP. } \\
\text { hen managed and co }\end{array}$ & $\begin{array}{l}\text { ragroup explo } \\
\text { ymanaged } \\
\text { oor EPO }\end{array}$ & the NL. & $\begin{array}{l}\text { Sources: } \\
\text { IBFD; ZEW (2 }\end{array}$ & 13); TR & D14); PWC & $\begin{array}{l}\text { Colour cod } \\
\text { Yes: } \\
\text { Yes, with re } \\
\text { No: } \\
\text { (2013); ACC }\end{array}$ & (2013); $\mathrm{Cac}$ & \begin{tabular}{|l|} 
\\
\\
\end{tabular} & tional legislatic & $n$ and rep & ts by PWC, & Deloitte anc & d KPMG. \\
\hline
\end{tabular}

Sources: European Commission

Table 3: Technology field of patent applications by sector 2000-2012.

Chemistry Electrical Instruments Mechanical Other fields Total

\begin{tabular}{|c|c|c|c|c|c|c|}
\hline & & engineering & & engineering & & \\
\hline Cars & $8.82 \%$ & $17.25 \%$ & $8.48 \%$ & $63.98 \%$ & $1.46 \%$ & 88,826 \\
\hline ICT & $4.14 \%$ & $81.01 \%$ & $9.82 \%$ & $4.77 \%$ & $0.26 \%$ & 165,187 \\
\hline Pharma & $79.50 \%$ & $1.63 \%$ & $17.11 \%$ & $1.60 \%$ & $0.16 \%$ & 75,859 \\
\hline Total & 74,982 & 150,380 & 36,737 & 65,920 & 1,853 & 329,872 \\
\hline
\end{tabular}

applications

Sources: European Commission, Patstat and OECD. 
Table 4: Summary statistics - base model

\begin{tabular}{|c|c|c|c|c|c|c|c|c|c|c|c|c|}
\hline \multirow[b]{3}{*}{ Patent count } & \multicolumn{4}{|c|}{ car } & \multicolumn{4}{|c|}{ ict } & \multicolumn{4}{|c|}{ pharma } \\
\hline & Min & Max & Mean & std. Dev. & Min & Max & Mean & std. Dev. & Min & Max & Mean & std. Dev. \\
\hline & 0.000 & 869.000 & 1.882 & 20.104 & 0.000 & 1249.000 & 1.651 & 25.553 & 0.000 & 598.000 & 1.064 & 12.534 \\
\hline Effective corporate income tax & 0.000 & 51.612 & 25.101 & 10.229 & 0.000 & 51.612 & 25.040 & 10.211 & 0.000 & 51.612 & 25.031 & 10.201 \\
\hline Statutory corporate income tax & 12.500 & 51.612 & 27.821 & 7.421 & 12.500 & 51.612 & 27.763 & 7.411 & 12.500 & 51.612 & 27.749 & 7.407 \\
\hline Tax advantage in patent box $(\mathrm{T})$ & 0.000 & 32.850 & 2.720 & 6.868 & 0.000 & 32.850 & 2.722 & 6.864 & 0.000 & 32.850 & 2.718 & 6.857 \\
\hline Non-tax patent box effect (NT) & 0.000 & 1.000 & 0.151 & 0.358 & 0.000 & 1.000 & 0.151 & 0.358 & 0.000 & 1.000 & 0.151 & 0.358 \\
\hline Business R\&D / GDP & 0.010 & 4.088 & 1.235 & 0.704 & 0.010 & 4.088 & 1.232 & 0.703 & 0.010 & 4.088 & 1.228 & 0.701 \\
\hline IP protection & 0.000 & 1.000 & 0.500 & 0.500 & 0.000 & 1.000 & 0.500 & 0.500 & 0.000 & 1.000 & 0.500 & 0.500 \\
\hline Real research activity & 0.000 & 1.000 & 0.096 & 0.294 & 0.000 & 1.000 & 0.081 & 0.273 & 0.000 & 1.000 & 0.091 & 0.288 \\
\hline GDP level (log) & 7.898 & 16.289 & 12.392 & 1.796 & 7.898 & 16.289 & 12.396 & 1.794 & 7.898 & 16.289 & 12.397 & 1.793 \\
\hline
\end{tabular}

Sources: Patstat for patent count; Patstat and OECD for Real research activity; OECD for Business R\&D; OECD for GDP; The Taxes in Europe Database, the OECD tax database and the IBFD database, as well as national ministries of finance websites, for the statutory rates and the patent characteristics; Ginarte and Park (1997), and Park (2008) for IP protection. 
Table 5: Basic Regressions

\begin{tabular}{|c|c|c|c|c|c|c|c|c|c|}
\hline \multirow{3}{*}{ Model estimated } & (1) & (2) & (3) & (4) & (5) & (6) & (7) & (8) & (9) \\
\hline & \multicolumn{3}{|c|}{ negative binomial } & \multicolumn{3}{|c|}{ negative binomial } & \multicolumn{3}{|c|}{ negative binomial - mixed model } \\
\hline & Pharma & ICT & Car & Pharma & ICT & Car & Pharma & ICT & Car \\
\hline \multirow[t]{2}{*}{ Effective corporate income tax } & $-0.032 * *$ & 0.014 & $-0.058 * * *$ & - & - & - & - & - & - \\
\hline & $(0.013)$ & $(0.014)$ & $(0.018)$ & - & - & - & - & - & - \\
\hline \multirow[t]{2}{*}{ Statutory corporate income tax } & - & - & - & $-0.141 * * *$ & -0.015 & $-0.056 * *$ & $-0.090 * * *$ & -0.043 & -0.037 \\
\hline & - & - & - & $(0.029)$ & $(0.035)$ & $(0.028)$ & $(0.023)$ & $(0.034)$ & $(0.025)$ \\
\hline \multirow[t]{2}{*}{ Tax advantage in patent box $(T)$} & - & - & - & $0.099 * * *$ & $0.073^{* * *}$ & $0.162^{* * *}$ & $0.073 * * *$ & $0.128^{* * *}$ & $0.234 * * *$ \\
\hline & & & & $(0.016)$ & $(0.017)$ & $(0.025)$ & $(0.015)$ & $(0.024)$ & $(0.037)$ \\
\hline \multirow[t]{2}{*}{$\begin{array}{l}\text { Tax advantage in patent box } \\
\text { (random effects) }\end{array}$} & - & - & - & - & - & - & 0.000 & $0.012 * * *$ & $0.016^{* *}$ \\
\hline & - & - & - & - & - & - & 0.000 & 0.004 & 0.007 \\
\hline \multirow[t]{4}{*}{ Non-tax patent box effect $(N T)$} & - & - & - & $-1.869^{* * *}$ & $-2.460 * * *$ & $-2.639 * * *$ & $-1.606 * * *$ & $-3.028 * * *$ & $-3.697 * * *$ \\
\hline & - & - & - & $(0.174)$ & $(0.210)$ & $(0.194)$ & $(0.169)$ & $(0.255)$ & $(0.318)$ \\
\hline & $0.584 *$ & 0.036 & -0.526 & $0.603^{* *}$ & $0.640^{*}$ & -0.506 & 0.218 & 0.518 & -0.265 \\
\hline & $(0.310)$ & $(0.407)$ & $(0.363)$ & $(0.289)$ & $(0.375)$ & $(0.366)$ & $(0.264)$ & $(0.323)$ & $(0.414)$ \\
\hline \multirow[t]{2}{*}{ IP protection } & $4.995^{* * *}$ & $4.793 * * *$ & $6.074 * * *$ & $4.886^{* * *}$ & $4.957 * * *$ & $6.103^{* * *}$ & $5.057 * * *$ & $4.970 * * *$ & $6.166^{* * *}$ \\
\hline & $(0.181)$ & $(0.179)$ & $(0.344)$ & $(0.162)$ & $(0.170)$ & $(0.341)$ & $(0.199)$ & $(0.211)$ & $(0.378)$ \\
\hline \multirow[t]{2}{*}{ Real research activity } & $9.341^{* * *}$ & $12.856^{* * *}$ & $10.378^{* * *}$ & $8.738 * * *$ & $11.475^{* * *}$ & $10.171^{* * *}$ & $7.291 * * *$ & $9.537 * * *$ & $10.261^{* * *}$ \\
\hline & $(0.176)$ & $(0.323)$ & $(0.221)$ & $(0.168)$ & $(0.301)$ & $(0.215)$ & $(0.153)$ & $(0.228)$ & $(0.266)$ \\
\hline \multirow[t]{2}{*}{ GDP level } & $2.679 * * *$ & 0.556 & $-3.411 * * *$ & $2.417 * * *$ & $1.264^{* *}$ & $-2.611^{* * *}$ & $1.064 * *$ & $1.507^{* *}$ & -0.653 \\
\hline & $(0.540)$ & $(0.625)$ & $(0.783)$ & $(0.563)$ & $(0.641)$ & $(0.812)$ & $(0.538)$ & $(0.627)$ & $(0.962)$ \\
\hline Observations & 55,200 & 75,392 & 29,792 & 55,200 & 75,392 & 29,792 & 55,200 & 75,392 & 29,792 \\
\hline Chi-square & 66,019 & 51,407 & 29,584 & 69,170 & 54,842 & 29,183 & 2,702 & 2,155 & 1,540 \\
\hline LR-test & 240,200 & 704,492 & 247,406 & 229,065 & 694,026 & 244,974 & 1,387 & 1,896 & 680.4 \\
\hline Prob $>=$ chibar2 & {$[0.000]$} & {$[0.000]$} & {$[0.000]$} & {$[0.000]$} & {$[0.000]$} & {$[0.000]$} & {$[0.000]$} & {$[0.000]$} & {$[0.000]$} \\
\hline \multirow[t]{2}{*}{ Alpha (overdispersion) } & 23.580 & 4.100 & 21.007 & 22.063 & 56.787 & 19.788 & & & \\
\hline & $(0.028)$ & $(0.030)$ & $(0.762)$ & $(0.631)$ & $(1.715)$ & $(0.719)$ & & & \\
\hline
\end{tabular}

Observations are clustered at the host country level. 
Table 6: High-quality patents

\begin{tabular}{|c|c|c|c|c|c|c|}
\hline \multirow{4}{*}{ Model estimated } & (1) & (2) & (3) & (4) & (5) & (6) \\
\hline & \multicolumn{3}{|c|}{ Negative binomial - high quality patents } & \multicolumn{3}{|c|}{ Negative binomial - other patents } \\
\hline & Pharma & ICT & Car & Pharma & ICT & car \\
\hline & & high quality pate & & & other patents & \\
\hline \multirow[t]{2}{*}{ Statutory corporate income tax } & $-0.269^{* * *}$ & $-0.165^{*}$ & $-0.221 * * *$ & $-0.069^{* *}$ & $0.058^{*}$ & -0.007 \\
\hline & $(0.044)$ & $(0.085)$ & $(0.067)$ & $(0.035)$ & $(0.035)$ & $(0.034)$ \\
\hline Tax advantage in patent box $(T)$ & $0.163^{* * *}$ & $0.086^{*}$ & $0.202 * * *$ & $0.082 * * *$ & $0.056^{* * *}$ & $0.188 * * *$ \\
\hline \multirow[t]{2}{*}{ Non-tax patent box effect $(N T)$} & $-2.470 * * *$ & $-2.510 * * *$ & $-3.128^{* * *}$ & $-1.572 * * *$ & $-1.999 * * *$ & $-2.782 * * *$ \\
\hline & $(0.346)$ & $(0.548)$ & $(0.371)$ & $(0.205)$ & $(0.213)$ & $(0.245)$ \\
\hline \multirow[t]{2}{*}{ Business R\&D / GDP } & $-1.428 * *$ & $-2.129 * *$ & $-3.026 * * *$ & $1.089^{* * *}$ & $1.766^{* * *}$ & 0.178 \\
\hline & $(0.658)$ & $(0.901)$ & $(0.763)$ & $(0.304)$ & $(0.338)$ & $(0.514)$ \\
\hline \multirow[t]{2}{*}{ IP protection } & $5.912 * * *$ & $4.287 * * *$ & $6.578^{* * * *}$ & $4.276^{* * *}$ & $4.621 * * *$ & $6.510^{* * * *}$ \\
\hline & $(0.389)$ & $(0.366)$ & $(0.550)$ & $(0.170)$ & $(0.171)$ & $(0.516)$ \\
\hline \multirow[t]{2}{*}{ Real research activity } & $8.339 * * *$ & $16.820^{* * *}$ & $7.632 * * *$ & $8.542 * * *$ & $9.801 * * *$ & $11.940 * * *$ \\
\hline & $(0.330)$ & $(0.924)$ & $(0.343)$ & $(0.182)$ & $(0.230)$ & $(0.309)$ \\
\hline GDP level & $(1.153)$ & $(1.390)$ & $(1.597)$ & $(0.633)$ & $(0.582)$ & $(1.224)$ \\
\hline Observations & 14,732 & 20,033 & 8,192 & 40,468 & 55,359 & 21,600 \\
\hline Chi-square & 17,009 & 10,583 & 11,862 & 54,725 & 50,256 & 15,580 \\
\hline LR-test & 68,496 & 175,564 & 39,173 & 152,565 & 487,186 & 198,317 \\
\hline country-fixed effects & yes & yes & yes & yes & yes & yes \\
\hline time fixed-effects & yes & yes & yes & yes & yes & yes \\
\hline $\begin{array}{l}\text { Chi-square equality of coefficients } \\
\text { between high quality patents and other } \\
\text { patents (tax advantage in patent box) }\end{array}$ & 77.19 & 127.21 & 19.91 & - & - & - \\
\hline Prob > chi 2 & 0.00 & 0.00 & 0.00 & - & - & - \\
\hline
\end{tabular}


Table 7: Patent box characteristics - pharmaceutical

\begin{tabular}{|c|c|c|c|c|c|}
\hline & (1) & (2) & (3) & (4) & (5) \\
\hline $\begin{array}{l}\text { Model estimated } \\
\text { Patent box characteristic }\end{array}$ & acquired patents & embedded royalties & $\begin{array}{l}\text { Negative binomial } \\
\text { existing patents }\end{array}$ & scope of patents & $\begin{array}{c}\text { developmen } \\
\text { conditions }\end{array}$ \\
\hline \multirow[t]{2}{*}{ dummy $=1$ if condition applies } & $2.577 * * *$ & -3.005 & $1.480 * * *$ & $-2.912 * * *$ & $2.828 * * *$ \\
\hline & $(0.414)$ & $(1.836)$ & $(0.364)$ & $(0.923)$ & $(0.407)$ \\
\hline \multirow[t]{2}{*}{ Tax advantage in the specific condition } & $0.159 * * *$ & 0.164 & $0.073 * *$ & $0.323 * * *$ & $-0.183^{* * *}$ \\
\hline & $(0.060)$ & $(0.130)$ & $(0.030)$ & $(0.089)$ & $(0.034)$ \\
\hline \multirow[t]{2}{*}{ Statutory corporate income tax } & -0.063 & 0.033 & 0.019 & $0.145^{*}$ & $0.277 * * *$ \\
\hline & $(0.104)$ & $(0.104)$ & $(0.085)$ & $(0.084)$ & $(0.092)$ \\
\hline \multirow[t]{2}{*}{ Business R\&D / GDP } & $2.826 * *$ & 1.691 & 0.323 & $2.005 * *$ & 1.579 \\
\hline & (1.128) & $(1.073)$ & $(1.110)$ & $(1.012)$ & $(1.056)$ \\
\hline \multirow{2}{*}{ IP protection } & $5.996^{* * * *}$ & $2.710^{* * * *}$ & $3.236^{* * *}$ & $4.203^{* * *}$ & $1.669^{* * *}$ \\
\hline & $(0.956)$ & $(0.460)$ & $(0.499)$ & $(0.660)$ & $(0.567)$ \\
\hline \multirow[t]{2}{*}{ Real research activity } & $7.774 * * *$ & $6.068^{* * * *}$ & $6.051 * * *$ & $6.016^{* * *}$ & $7.439 * * *$ \\
\hline & $(0.417)$ & $(0.237)$ & $(0.237)$ & $(0.234)$ & $(0.365)$ \\
\hline \multirow[t]{2}{*}{ GDP level } & $3.609^{* *}$ & $6.753^{* * * *}$ & $4.735^{* * *}$ & $6.977 * * *$ & $5.715^{* * *}$ \\
\hline & $(1.560)$ & $(1.269)$ & $(1.369)$ & $(1.326)$ & $(1.435)$ \\
\hline Observations & 8,347 & 8,347 & 8,347 & 8,347 & 8,347 \\
\hline Chi-square & 12,504 & 15,430 & 15,410 & 15,319 & 13,068 \\
\hline LR-test & 9,865 & 9,926 & 9,969 & 9,986 & 9,595 \\
\hline country-fixed effects & yes & yes & yes & yes & yes \\
\hline time fixed-effects & yes & yes & yes & yes & yes \\
\hline
\end{tabular}

Standard errors in parentheses. ${ }^{* * *} \mathrm{p}<0.01, * * \mathrm{p}<0.05,{ }^{*} \mathrm{p}<0.1$. We use as exposure variable the total number of employees of a company (including its subsidiaries). Observations are clustered at the host country level. 
Table 8: Patent box characteristics - ICT

\begin{tabular}{|c|c|c|c|c|c|}
\hline & (1) & (2) & (3) & (4) & (5) \\
\hline $\begin{array}{l}\text { Model estimated: negative binomial } \\
\text { Patent box characteristic }\end{array}$ & acquired patents & embedded royalties & existing patents & scope of patents & $\begin{array}{l}\text { development } \\
\text { conditions }\end{array}$ \\
\hline \multirow[t]{2}{*}{ dummy $=1$ if condition applies } & $1.004^{* *}$ & $-5.493^{* *}$ & $-1.121 * *$ & $-9.986 * * *$ & $1.401 * * *$ \\
\hline & $(0.431)$ & $(2.754)$ & $(0.536)$ & $(1.693)$ & $(0.539)$ \\
\hline \multirow{2}{*}{ Tax advantage in the specific condition } & $0.352 * * *$ & $0.486 * * *$ & 0.067 & $0.858 * * *$ & -0.032 \\
\hline & $(0.075)$ & $(0.186)$ & $(0.041)$ & $(0.164)$ & $(0.035)$ \\
\hline Statutory corporate income tax & $-0.218^{*}$ & -0.218 & 0.092 & $-0.214^{*}$ & 0.083 \\
\hline \multirow{2}{*}{ Business R\&D / GDP } & $5.478 * * *$ & $6.455 * * *$ & $7.147 * * *$ & $5.609 * * *$ & $4.543^{* * *}$ \\
\hline & $(1.162)$ & (1.396) & $(1.560)$ & $(1.168)$ & $(1.179)$ \\
\hline \multirow{2}{*}{ IP protection } & $5.922 * * *$ & $2.713 * * *$ & $2.404 * * *$ & $4.276^{* * *}$ & $1.011^{*}$ \\
\hline & $(1.167)$ & $(0.674)$ & $(0.613)$ & $(1.257)$ & $(0.598)$ \\
\hline \multirow{2}{*}{ Real research activity } & $9.258 * * *$ & $8.735 * * *$ & $8.609^{* * *}$ & $8.581 * * *$ & $9.064 * * *$ \\
\hline & $(0.419)$ & $(0.366)$ & $(0.348)$ & $(0.342)$ & $(0.409)$ \\
\hline \multirow{2}{*}{ GDP level } & -1.410 & 0.718 & 1.815 & 2.950 & 0.378 \\
\hline & $(1.827)$ & $(1.837)$ & (1.904) & $(1.836)$ & $(1.700)$ \\
\hline Observations & 11,409 & 11,409 & 11,409 & 11,409 & 11,409 \\
\hline Chi-square & 8,400 & 9,158 & 9,477 & 8,828 & 9,171 \\
\hline LR-test & 98,010 & 103,807 & 103,644 & 100,310 & 97,464 \\
\hline country-fixed effects & yes & yes & yes & yes & yes \\
\hline time fixed-effects & yes & yes & yes & yes & yes \\
\hline
\end{tabular}


Table 9: Patent box characteristics - car

\begin{tabular}{|c|c|c|c|c|c|}
\hline & (1) & (2) & (3) & (4) & (5) \\
\hline $\begin{array}{l}\text { Model estimated } \\
\text { Patent box characteristic }\end{array}$ & acquired patents & embedded royalties & $\begin{array}{c}\text { Negative binomial } \\
\text { existing patents }\end{array}$ & scope of patents & $\begin{array}{r}\text { developmen } \\
\text { conditions } \\
\end{array}$ \\
\hline dummy $=1$ if specific condition applies in the patent box regime & $\begin{array}{c}-7.126^{* * *} \\
(1.364)\end{array}$ & $\begin{array}{c}-15.399 * * * \\
(5.947)\end{array}$ & $\begin{array}{c}3.938 * * * \\
(0.953)\end{array}$ & $\begin{array}{c}-8.001 * * * \\
(1.833)\end{array}$ & $\begin{array}{c}-4.521 * * * \\
(1.751)\end{array}$ \\
\hline Tax advantage in the specific condition & $\begin{array}{c}0.458^{* * * *} \\
(0.157)\end{array}$ & $\begin{array}{c}0.874 * * \\
(0.413)\end{array}$ & $\begin{array}{c}-0.321^{* * *} \\
(0.088)\end{array}$ & $\begin{array}{c}0.648 * * * \\
(0.158)\end{array}$ & $\begin{array}{c}0.038 \\
(0.145)\end{array}$ \\
\hline Statutory corporate income tax & $\begin{array}{l}0.432 * \\
(0.254)\end{array}$ & $\begin{array}{c}0.025 \\
(0.240)\end{array}$ & $\begin{array}{c}0.225 \\
(0.232)\end{array}$ & $\begin{array}{c}0.144 \\
(0.237)\end{array}$ & $\begin{array}{c}0.059 \\
(0.280)\end{array}$ \\
\hline Business R\&D / GDP & $\begin{array}{c}-5.321 * * \\
(2.247)\end{array}$ & $\begin{array}{c}-5.462 * * \\
(2.516)\end{array}$ & $\begin{array}{l}-4.297 * \\
(2.555)\end{array}$ & $\begin{array}{l}-3.878^{*} \\
(2.258)\end{array}$ & $\begin{array}{l}-0.560 \\
(2.415)\end{array}$ \\
\hline IP protection & $\begin{array}{c}1.821 \\
(1.565)\end{array}$ & $\begin{array}{c}0.190 \\
(0.957)\end{array}$ & $\begin{array}{c}0.355 \\
(0.909)\end{array}$ & $\begin{array}{c}2.217 \\
(1.462)\end{array}$ & $\begin{array}{c}2.776 * * * \\
(0.908)\end{array}$ \\
\hline Real research activity & $\begin{array}{c}10.260 * * * \\
(0.781)\end{array}$ & $\begin{array}{c}11.720 * * * \\
(0.889)\end{array}$ & $\begin{array}{c}10.949 * * * \\
(0.797)\end{array}$ & $\begin{array}{c}11.742^{* * *} \\
(0.836)\end{array}$ & $\begin{array}{c}9.312 * * * \\
(0.786)\end{array}$ \\
\hline GDP level & $\begin{array}{l}8.910^{* *} \\
(4.520)\end{array}$ & $\begin{array}{c}4.900 \\
(4.772)\end{array}$ & $\begin{array}{c}6.258 \\
(4.534)\end{array}$ & $\begin{array}{c}4.118 \\
(5.168)\end{array}$ & $\begin{array}{c}6.364 \\
(4.262)\end{array}$ \\
\hline Observations & 4,492 & 4,492 & 4,492 & 4,492 & 4,492 \\
\hline Chi-square & 2,570 & 2,744 & 2,824 & 2,646 & 2,717 \\
\hline LR-test & 25,802 & 24,894 & 23,896 & 26,702 & 23,702 \\
\hline country-fixed effects & yes & yes & yes & yes & yes \\
\hline time fixed-effects & yes & yes & yes & yes & yes \\
\hline
\end{tabular}


Table 10: Impact of patent boxes on real activity

\begin{tabular}{|c|c|c|c|c|c|c|}
\hline & (1) & (2) & (3) & (4) & (5) & (6) \\
\hline VARIABLES & Pharma & ICT & car & Pharma & ICT & car \\
\hline \multirow[t]{2}{*}{ Statutory corporate income tax } & $-0.037^{* *}$ & -0.013 & $-0.054 * * *$ & $-0.043^{* *}$ & -0.028 & $-0.058 * * *$ \\
\hline & $(0.018)$ & $(0.029)$ & $(0.018)$ & $(0.018)$ & $(0.024)$ & $(0.018)$ \\
\hline \multirow[t]{2}{*}{ Tax advantage in patent box } & $-0.092 * * *$ & $-0.088 * * *$ & $-0.201 * * *$ & $-0.091 * * *$ & $-0.073 * *$ & $-0.165^{* * *}$ \\
\hline & $(0.032)$ & $(0.026)$ & $(0.051)$ & $(0.031)$ & $(0.031)$ & $(0.045)$ \\
\hline \multirow[t]{2}{*}{ Development conditions are required in the patent box } & $2.098 * * *$ & $1.944 * * *$ & $3.841 * * *$ & $2.059^{* * *}$ & $1.520^{* * *}$ & $3.109^{* * *}$ \\
\hline & $(0.712)$ & $(0.561)$ & $(1.025)$ & $(0.676)$ & $(0.629)$ & $(0.982)$ \\
\hline \multirow[t]{2}{*}{ Business R\&D / GDP } & 0.439 & 0.275 & -0.009 & 0.394 & 0.220 & 0.019 \\
\hline & $(0.291)$ & $(0.323)$ & $(0.304)$ & $(0.284)$ & $(0.289)$ & $(0.308)$ \\
\hline \multirow[t]{2}{*}{ Intellectual property protection } & $0.982 * *$ & -0.252 & 0.022 & $1.126^{* *}$ & 0.195 & 0.482 \\
\hline & $(0.472)$ & $(0.405)$ & $(0.582)$ & $(0.495)$ & $(0.422)$ & $(0.574)$ \\
\hline \multirow[t]{2}{*}{ Real research activity } & & & & 0.462 & $1.678^{* * *}$ & $1.729^{* *}$ \\
\hline & & & & $(0.331)$ & $(0.321)$ & $(0.723)$ \\
\hline \multirow[t]{2}{*}{ GDP level } & 0.653 & 0.555 & 0.536 & 0.557 & 0.521 & 0.502 \\
\hline & $(0.680)$ & $(0.592)$ & $(0.755)$ & $(0.661)$ & $(0.569)$ & $(0.731)$ \\
\hline \multirow[t]{2}{*}{ Constant } & $-1.899 * * *$ & $-1.546 * * *$ & $-1.024 * *$ & $-2.263 * * *$ & $-2.718 * * *$ & $-2.466 * * *$ \\
\hline & $(0.428)$ & $(0.369)$ & $(0.499)$ & $(0.520)$ & $(0.455)$ & $(0.732)$ \\
\hline Observations & 3,193 & 3,537 & 1,963 & 3,193 & 3,537 & 1,963 \\
\hline Chi-square & 165.2 & 219.2 & 353.3 & 163.6 & 191.6 & 359.5 \\
\hline Pseudo R2 & 0.0424 & 0.0358 & 0.0525 & 0.0460 & 0.0843 & 0.0723 \\
\hline
\end{tabular}

Standard errors in parentheses. $* * * \mathrm{p}<0.01, * * \mathrm{p}<0.05, * \mathrm{p}<0.1$. We use as exposure variable the total number of employees of a company (including its subsidiaries). Observations are clustered at the host country level 
Figure 1: Average Corporate Tax Rate and Patent Boxes in the EU-28

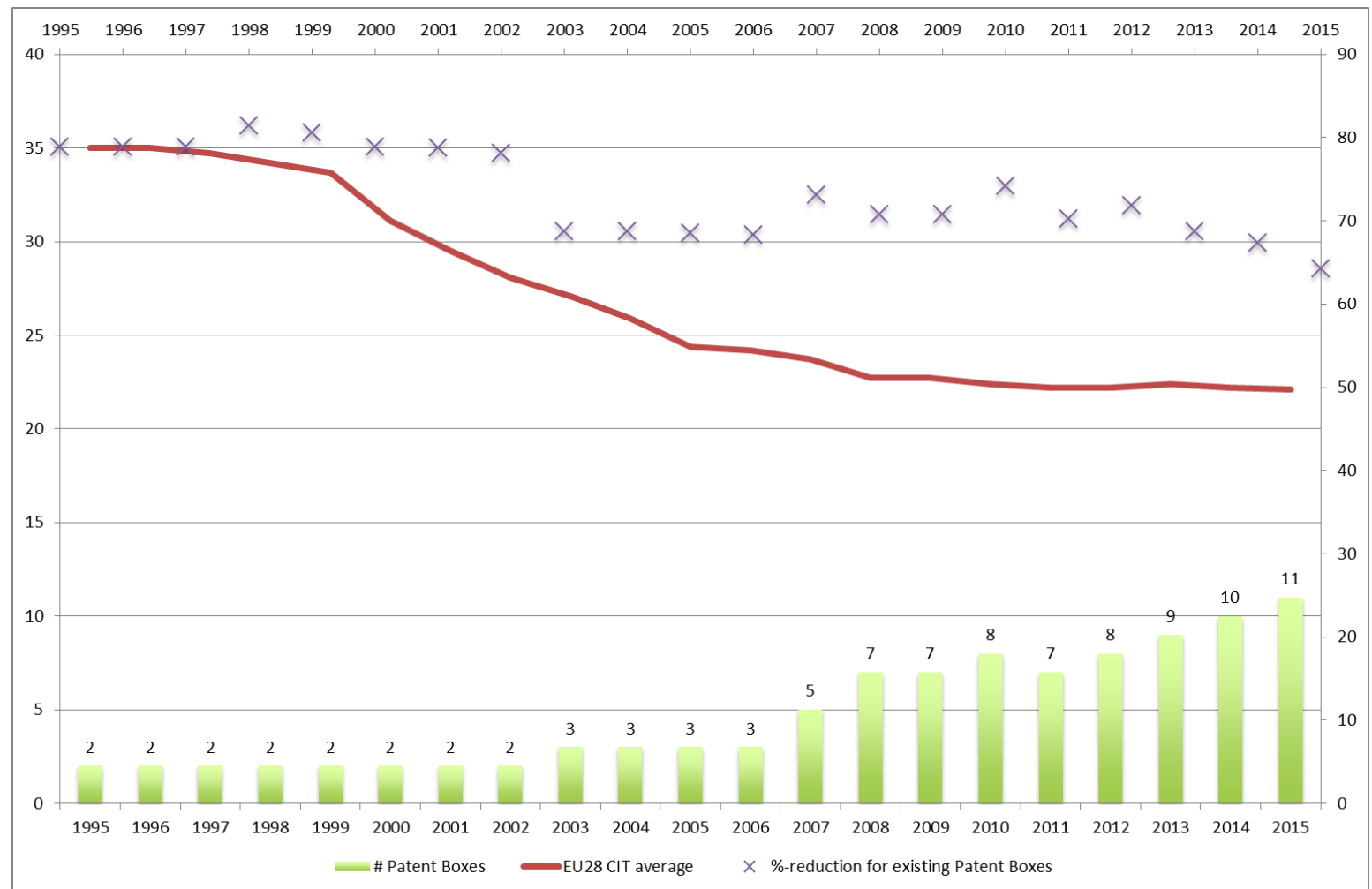

Sources: Taxes in Europe Database and own computations. The columns indicate the number of patent box regimes in the EU-28 and the crosses indicate the arithmetic average of the percentage reduction in corporate income taxes offered by the patent boxes. The straight line represents the arithmetic average statutory tax rate in the EU-28, including local taxes and surcharges. 
Figure 2: Predicted percentage change in the number of patents at levels of corporate tax rebate conditional on the existence of a patent box regime

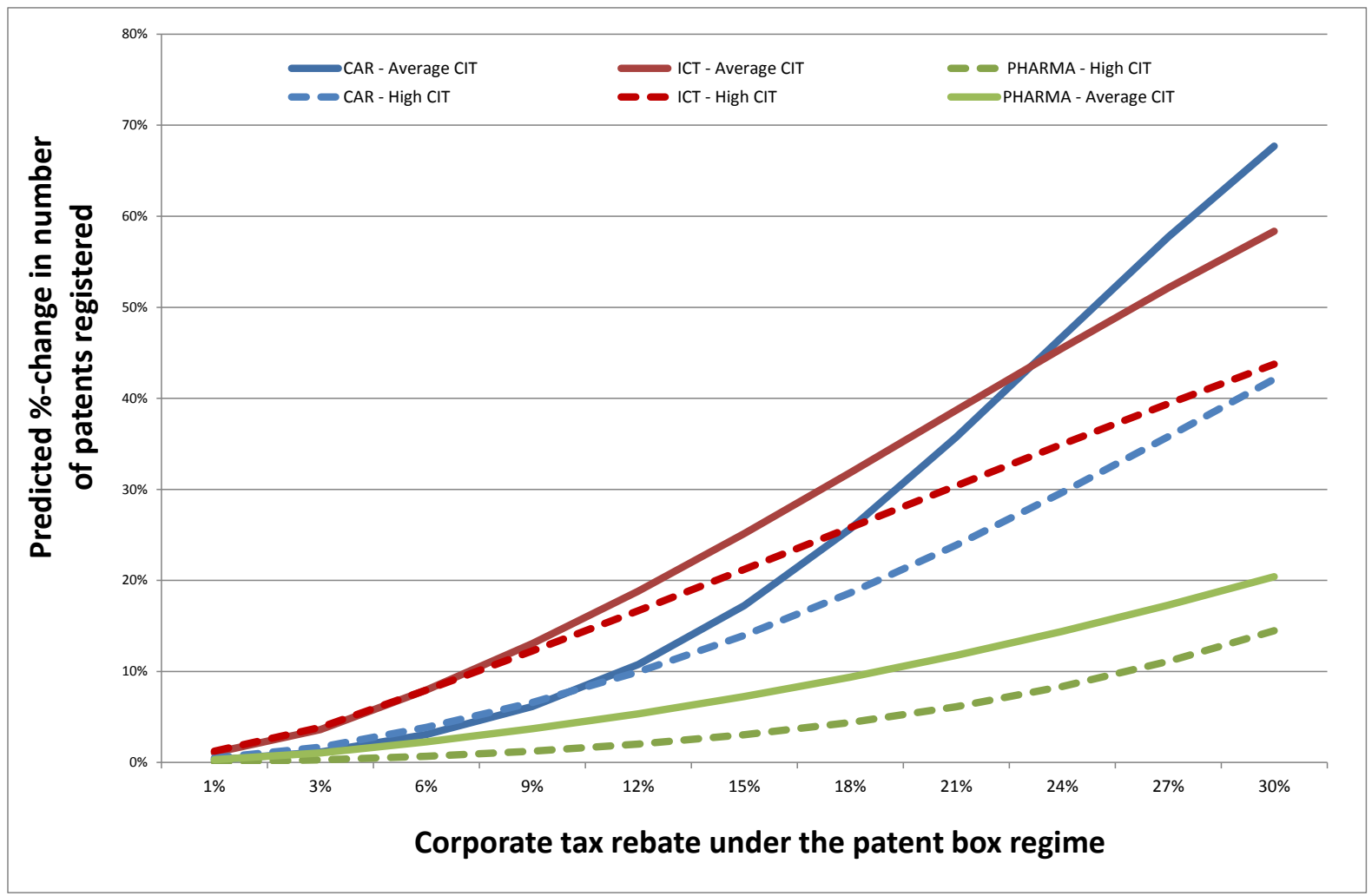


Figure 3: Average effective corporate tax paid on patent revenues: high- vs. low-quality patents
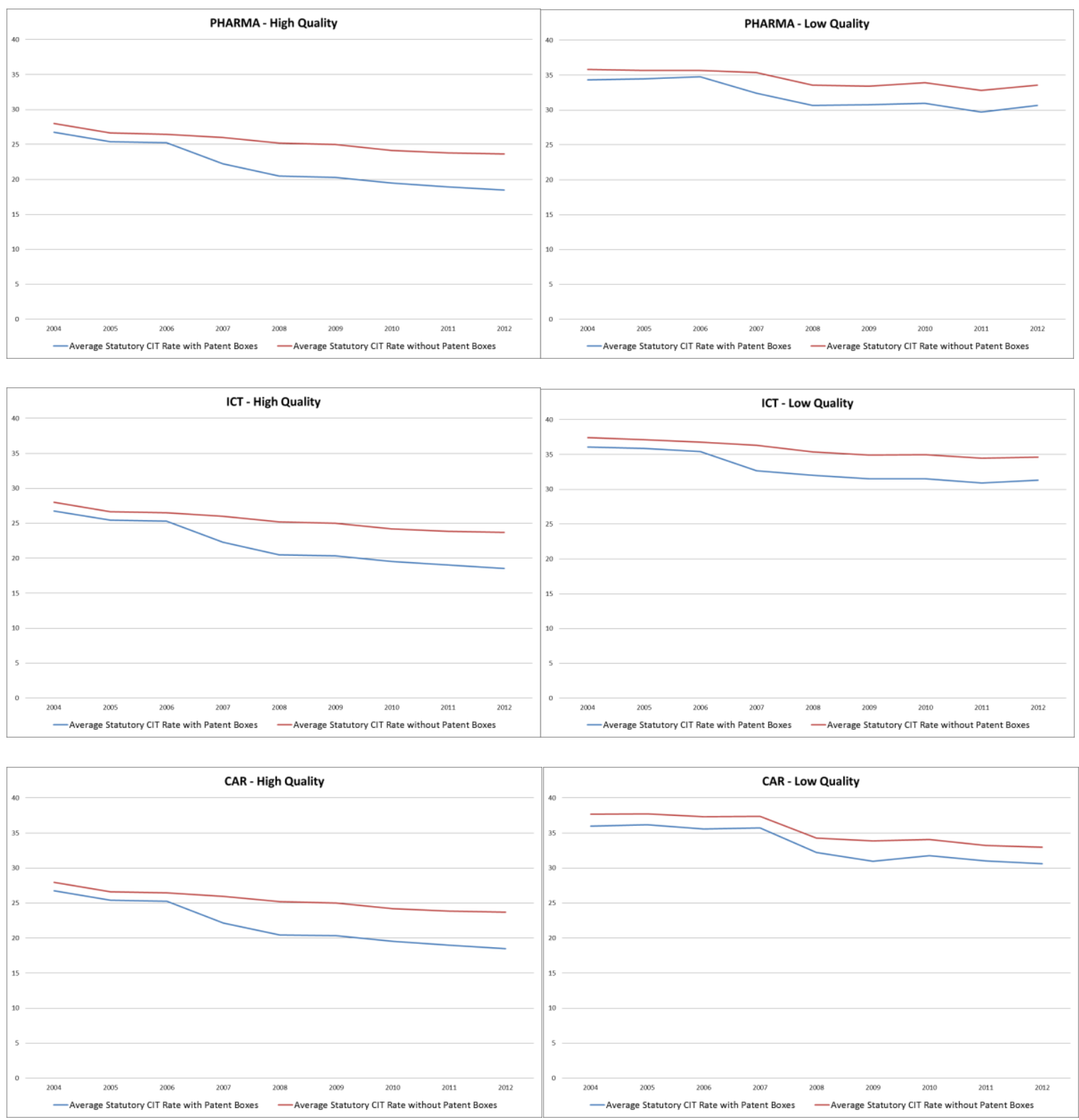
Figure 4: Predicted probability of attracting R\&D activities in presence of development conditions and at levels of corporate tax rebate in the patent box regime

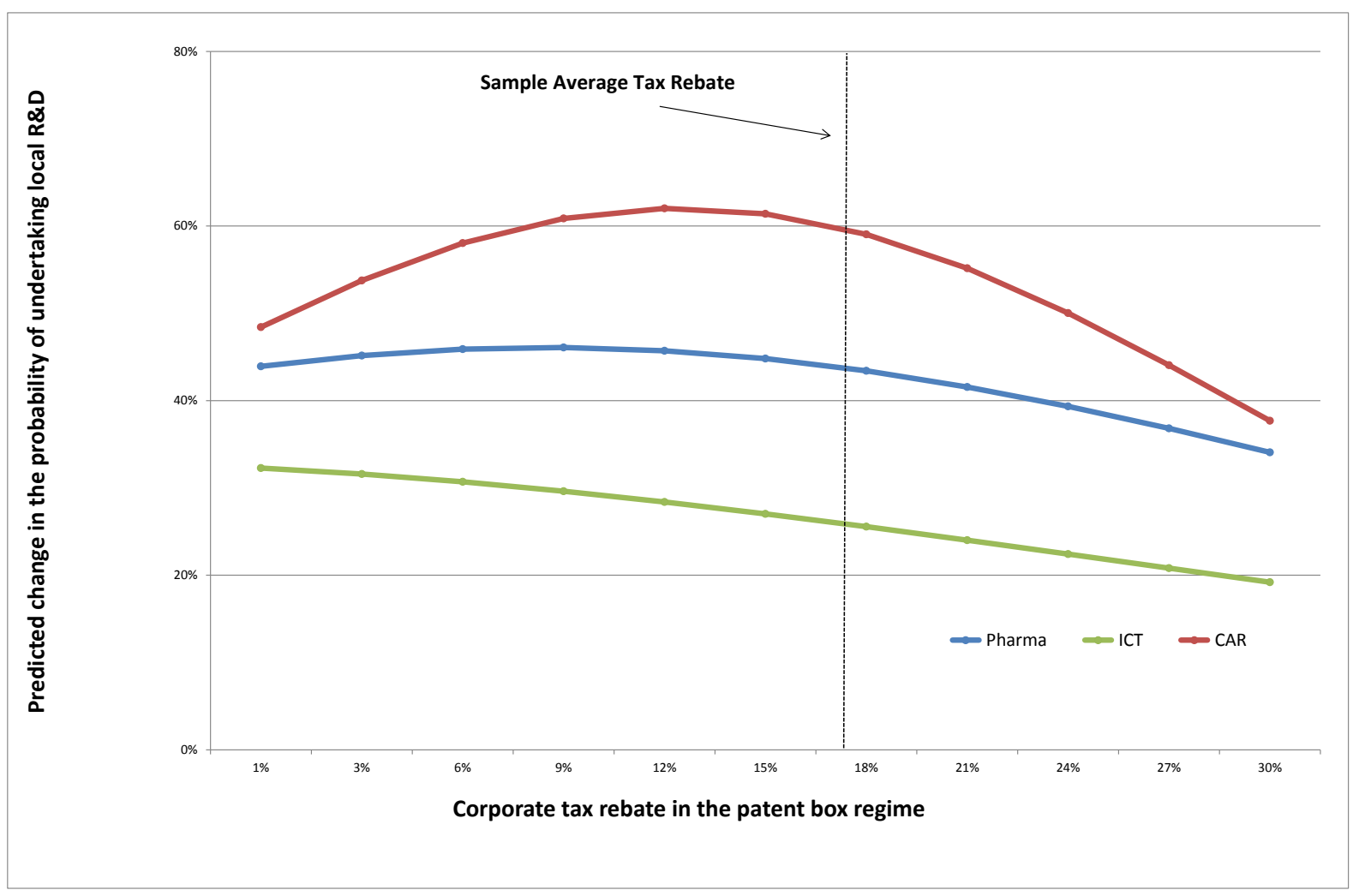

